\title{
Development of mine underground transportation with use of suspended monorails
}

\begin{abstract}
The development of suspended monorails is presented, indicating their advantages and limitations in use. Attention is paid to the development of monorails with battery drives in recent years. Example solutions including those developed in KOMAG-PCA-1 and GAD-1drive trains are given. The development of computer tools supporting designers and users of suspended monorails is described. Directions of further development of suspended transportation are discussed.
\end{abstract}

Key words: mine suspended monorails, drives: cable, diesel, battery, virtual prototyping, direction of further development

\section{INTRODUCTION}

Transportation of materials and run-of-mine as well as personnel movement are the most-important processes in mining operations. As long as floor transportation has been used from the beginning of the mining industry and first rail tracks appeared in the 17th century, the first use of suspended transportation took place in the mid-20th century. Designing state-of-the-art rope winches with the rope fixed to the roof (Fig. 1) on which transportation carriages were moved manually or by winches contributed to the development of suspended transportation.

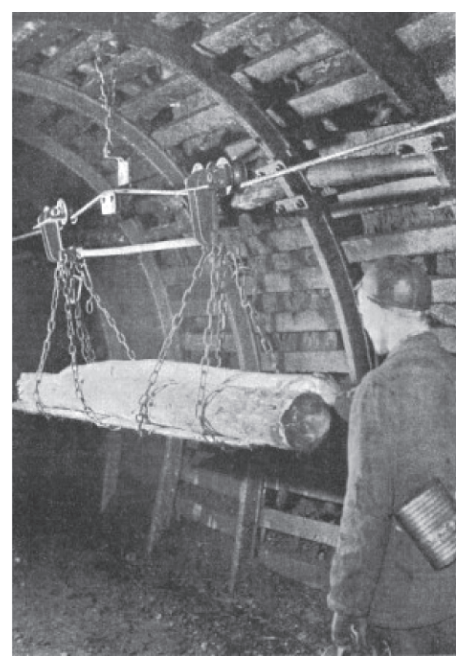

Fig. 1. Suspended rope transportation [1]
In the first half of the 1950s in Germany, a typical rail used in mine transportation was applied as the carrying component (Fig. 2) on which transportation carriages pulled by the rope were moved with loads of up to $1000 \mathrm{~kg}$ [2].

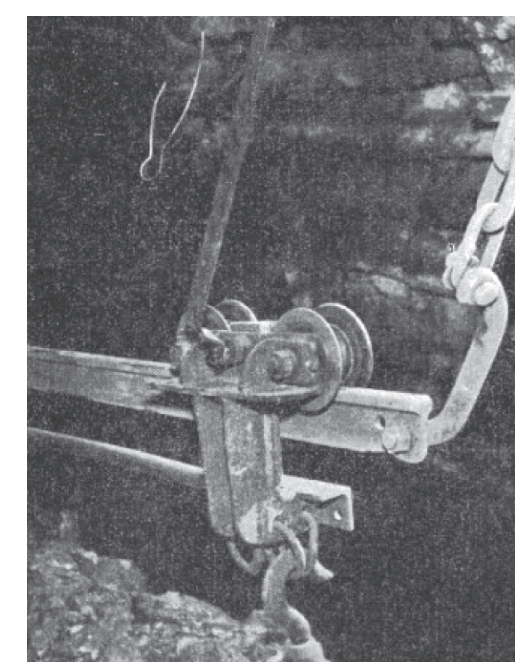

Fig. 2. Suspended monorail [4]

In 1956, the German company Scharf implemented the double-T bar as the carrying component in cable drive transportation (Fig. 3). The transportation set consisted of a pulling trolley, transportation cars with manual hoists and containers, and a braking trolley. Such a system became popular in German, English, and French mines [2]. 


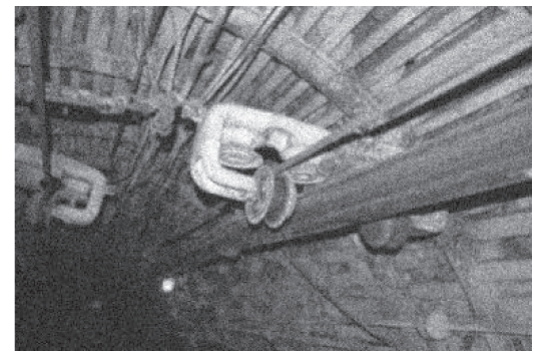

Fig. 3. Suspended monorail (double-T track) with rope drive [1]

The development of such transportation in Western Europe was a motivation to undertake the realization of such projects in KOMAG. At the beginning of the 1960s, KOMAG entered into collaboration with FMG PIOMA, the result of which was the development and commercialization (based on the license of the Becroit company) as well as implementation of the KSP-32 rope-driven monorail in mine undergrounds (also for the movement of people); they followed this with the KSP-63-type monorail. They became popular underground means of transportation - for example, FMG PIOMA S.A. implemented 1200 KSP-32 locomotives through 1992 [3]. Progress in the development of suspended monorails resulted in increases in the carrying capacity and strength of rail routes and transportation sets as well as an increase in the pulling force of the rope drive. Experience gained during the operation of rope-driven monorails indicated the following disadvantages:

- the possibility of transportation only along a previously determined route,

- a lack of visual contact of the operator with the transportation set,

- the possibility of an uncontrolled break of the pulling rope, which can cause a serious accident,

- the required costs for rope maintenance and guiding rollers on the transportation route.

At the end of the 1960s, the development of ropedriven monorails practically ended in Western Europe; however, according to authors' knowledge, 48 rope-driven monorails are in operation in Poland (as of December 31, 2016). Rope drives have been replaced by mobile traction devices - a suspended drive train (locomotive) with a diesel drive. The first prototype solutions of English companies were demonstrated in 1965. The German company Ruhrthaler started their commercial application, implementing a two-cabin HL $32 \mathrm{H}$ drive train in German and
French mines in 1967. Drive trains (locomotives) made by Scharf from Germany and Stephanoise from France (1970) were the next commercialized solutions. In 1967, a research project on the development of such solutions started in Czechoslovakia in Prievidza (Bansky Vyskumny Ustav).

Together with the development of drive trains (locomotives), suspended monorail tracks were improved by increasing their carrying capacity as well as modernizing their connections and suspensions. According to the German DIN standard, profile I 140 (I 155 according to the Polish PN standard) became commonly used instead of I 120 profiles, and now profile I 250 is also used. Designs of carrying and braking trolleys as well as transportation sets (including hoists) were also modernized [2].

\section{DEVELOPMENT OF SUSPENDED MONORAILS WITH DIESEL DRIVES USED IN POLISH HARD COAL MINES}

In 1976, the first Polish Lps-80 diesel locomotive (drive train) for suspended monorails was developed in KOMAG, and it was later manufactured by Zakłady Urządzeń Naftowych i Gazowniczych in Krosno, Poland in 1979. During the years of 19791980, the first tests were conducted in the KWK Ziemowit Mine, allowing workers to gain operational experience. An SW-400 engine, requiring periodic adjustment due to the necessity of obtaining the required quality (purity) of the exhaust gases, was used in the drive. The engine drove the Rauch pump of changing efficiency $\left(0-10 \mathrm{dm}^{3} / \mathrm{min}\right)$ and a pressure of $20 \mathrm{MPa}$ and this pump drove the SW-160 hydraulic motors made by HYDROSTER. Exhaust after-treatment and the cooling system kept temperatures of the exhaust gases below the required $70^{\circ} \mathrm{C}$ [4].

On the basis of the Lps-80 locomotive's (drive train) operation test, documentation of the prototype Lps-90D suspended diesel locomotive (Fig. 4) was developed in 1980. The abovementioned diesel engine was also used as the drive of this locomotive along with the verified protection system, assuring the required purity level of the exhaust gases as well as their outlet temperature. A Rexroth PAG AZP250 pump with an installed set power controller as well as an efficiency and flow-direction remote (hydraulic) controller and a set of two gear pumps were used. 


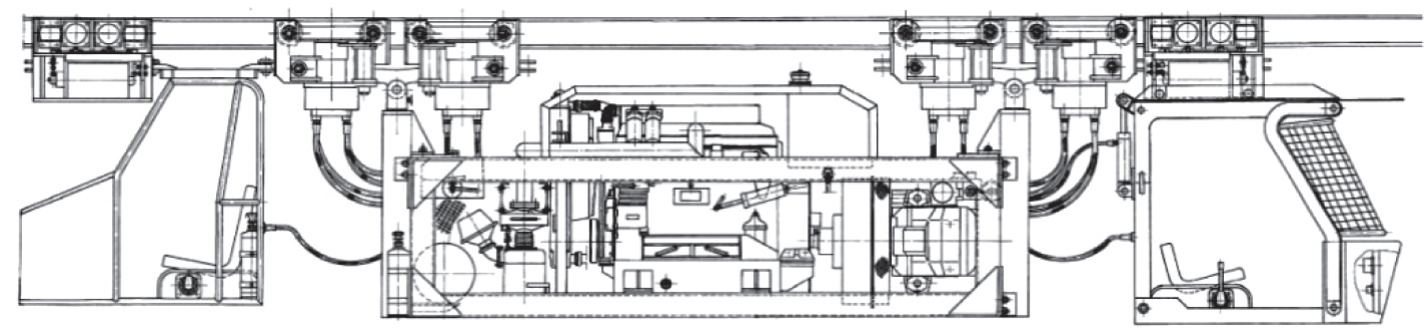

Fig. 4. Lps-90D suspended monorail locomotive [4]

The pump drove the SOK-160K hydraulic motor made by Hydroster. The prototype manufactured in 1982 by Zakład Naprawczy Taboru Samochodowego i Sprzętu in Brzesko (now Małopolska Wytwórnia Maszyn Brzesko Sp. z o.o.) underwent operational tests in the Murcki Mine and then in the Piast Mine. These tests confirmed the proper operation of most of the units. The low durability of the driving wheel's friction lining was the major problem [4].

During the years 1993-1996, the above experience was used during the realization of the "Underground transportation system for a suspended monorail with diesel drive" target project realized in collaboration with FMG PIOMA S.A. (now FAMUR S.A.). The LPS-90 locomotive (diesel drive train) (Fig. 5), designed to drive a suspended monorail for the transportation of materials, parts of machines, and equipment as well as personnel movement in mine workings with the potential hazard of methane and/or coal dust explosion, was developed, manufactured and tested in the laboratory and in situ.

a)

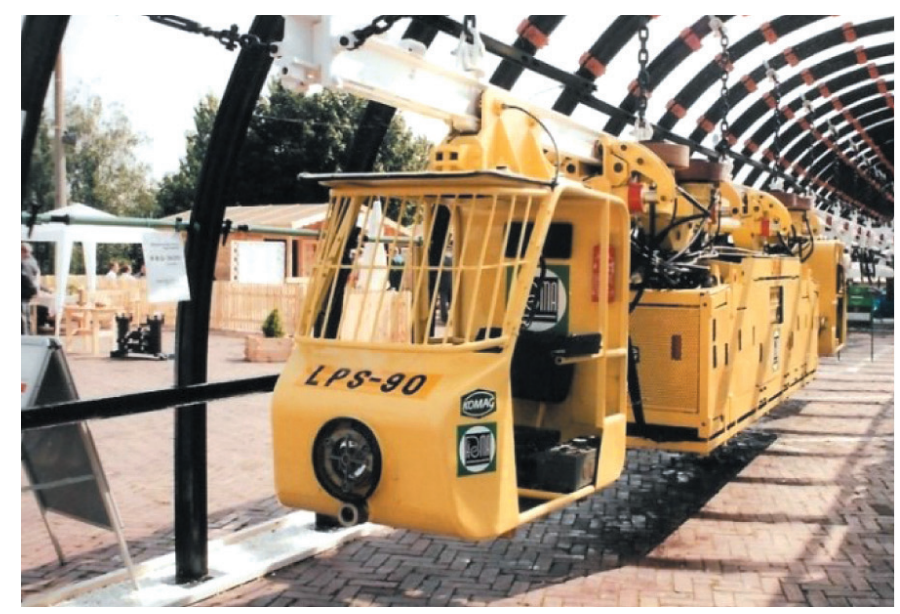

Realization of the project contributed to the further development of suspended monorails with diesel drives at FMG PIOMA S.A. (now FAMUR S.A.) - Figure 6.

The implementation of a suspended monorail with a diesel drive took place in Polish coal mines in the first half of the 1990s. According to the authors, at the end of 1995, 35 such machines were being used in the following mines: the Ziemowit, Piast, Bogdanka (6 machines each), Mysłowice (4 machines), Wesoła, Staszic (3 machines each), Murcki, Czeczott (2 machines each), Brzeszcze, Janina, and Andaluzja Mines (1 machine each). These were machines manufactured by Ruhrthaler, Scharf, BVU Prievidza, and ORTAS Pribram. According to the authors, 566 suspended monorail locomotives (drive trains) with diesel drives are currently being used in Polish coal mines (as of December 31, 2016). The leading suppliers are BECKER-WARKOP Ltd., FAMUR S.A., SCHARF, BEVEX, and FERRIT. Figure 7 shows samples of the currently available locomotives (drive trains) with diesel drives; their basic parameters are presented in Table 1.

b)

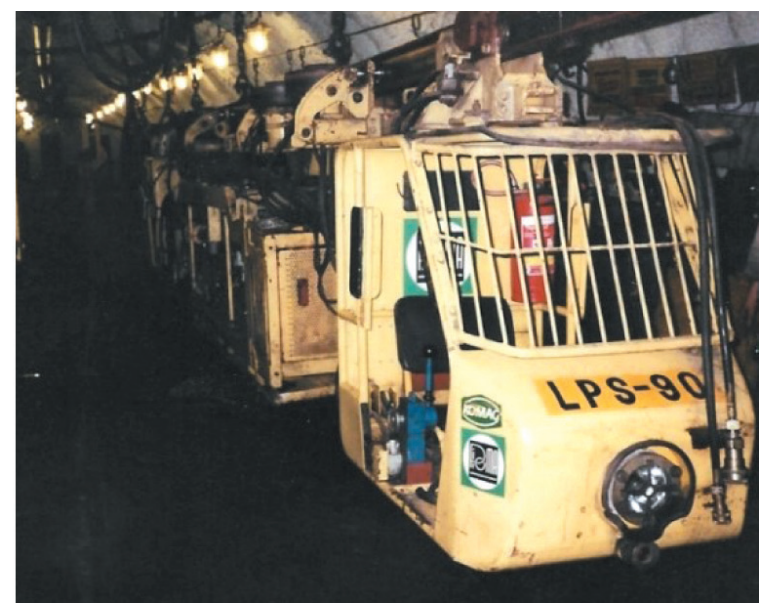

Fig. 5. LPS-90 locomotive (drive train): a) at KATOWICE'95 Fair; b) in underground working [5] 

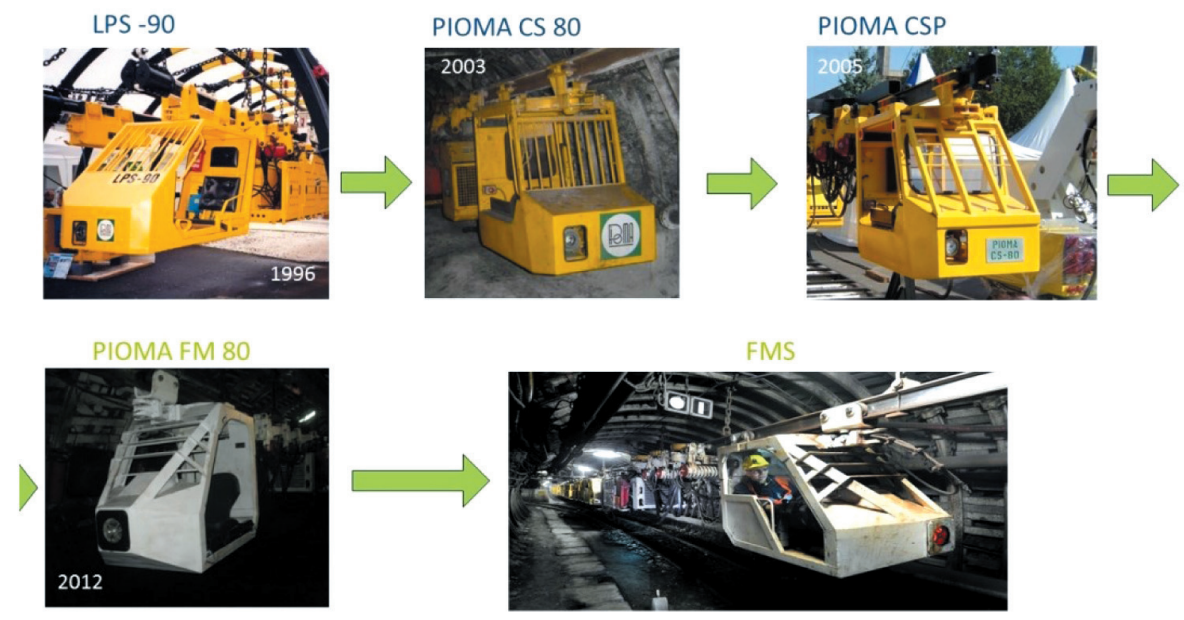

Fig. 6. Development of diesel monorails in FMG PIOMA S.A./FAMUR S.A [5]

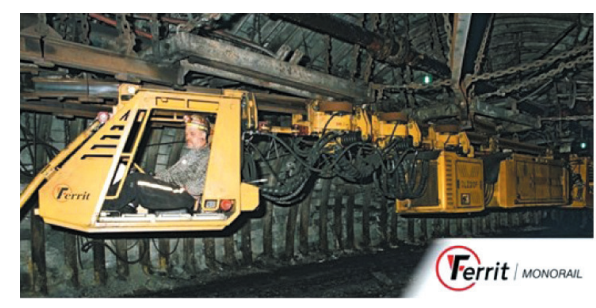

DLZ110F and DLZ210F by Ferrit



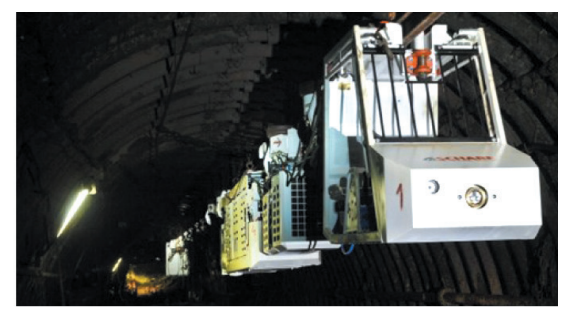

DZ 80 by Scharf

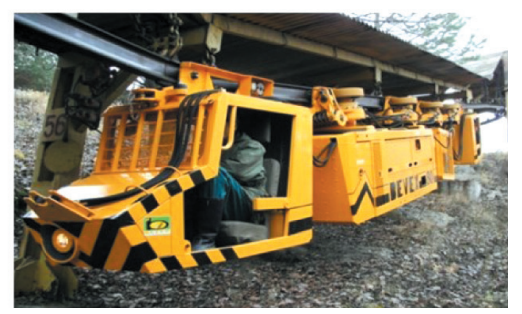

Fig. 7. Currently offered diesel monorails [5]

Table 1

Basic parameters of selected diesel driven trains [5]

\begin{tabular}{|c|c|c|c|c|c|c|c|}
\hline Type & $\begin{array}{l}\text { Manufa } \\
\text { cturer }\end{array}$ & $\begin{array}{l}\text { Max. pulling } \\
\text { force }[\mathrm{kN}]\end{array}$ & $\begin{array}{l}\text { Number } \\
\text { of driving } \\
\text { trolleys }\end{array}$ & $\begin{array}{l}\text { Max. speed } \\
{[\mathrm{m} / \mathrm{s}]}\end{array}$ & $\begin{array}{c}\text { Max. } \\
\text { inclination } \\
{\left[{ }^{\circ}\right]} \\
\end{array}$ & $\begin{array}{c}\text { Diesel engine } \\
\text { power } \\
{[\mathrm{kW}]}\end{array}$ & $\begin{array}{l}\text { Diesel engine } \\
\text { manufac-turer }\end{array}$ \\
\hline KP-95 & $\begin{array}{l}\text { Becker- } \\
\text { Warkop }\end{array}$ & $40-240$ & $2-12$ & 2.5 & 30 & 80-95 & Deutz \\
\hline KP-96 & $\begin{array}{l}\text { Becker- } \\
\text { Warkop }\end{array}$ & $40-240$ & $2-12$ & 2.5 & 30 & 96 & Perkins \\
\hline KP-148 & $\begin{array}{l}\text { Becker- } \\
\text { Warkop }\end{array}$ & $40-240$ & $2-12$ & 2.5 & 30 & 148 & Deutz \\
\hline FMS & Famur & $85 / 105 / 120 / 140$ & $4 / 5 / 6 / 7$ & 2.5 & 30 & 81 or 95 & Deutz \\
\hline $\mathrm{CSZ}$ & Famur & $85 / 105 / 120 / 140$ & $4 / 5 / 6 / 7$ & 2.6 & 30 & 123 & Deutz \\
\hline DZ 80 & Scharf & 160 & $3-8$ & 2 & 30 & 80 & Liebherr \\
\hline DZ 130 & Scharf & 160 & $3-8$ & 2.5 & 30 & 130 & Liebherr \\
\hline DLZ 110F & Ferrit & $60-140$ & $4-7$ & 2.0 & 30 & 81 & Zetor \\
\hline DLZ 210F & Ferrit & 110-330 & $4-12$ & 3.1 & 30 & $127-142$ & John Deere \\
\hline LZH120D5.1 & Ortas & $80 / 100 / 120$ & $4 / 5 / 6$ & $2.0 / 1.7 / 1.4$ & 30 & 81 & Zetor \\
\hline BEVEX 80 & Bevex & $60 / 80 / 100$ & $3 / 4 / 5$ & $2.0 / 1.8 / 1.5$ & 25 & 81 & - \\
\hline BEVEX 90 & Bevex & $80 / 100 / 120$ & $4 / 5 / 6$ & $2.0 / 1.8 / 1.5$ & 30 & 91 & - \\
\hline
\end{tabular}


a)

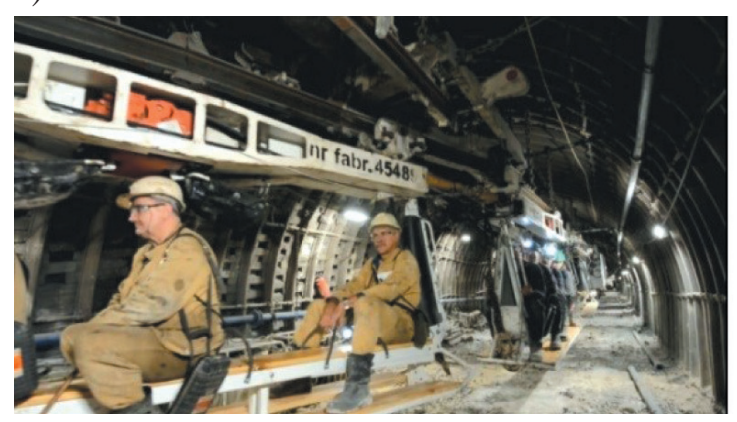

b)

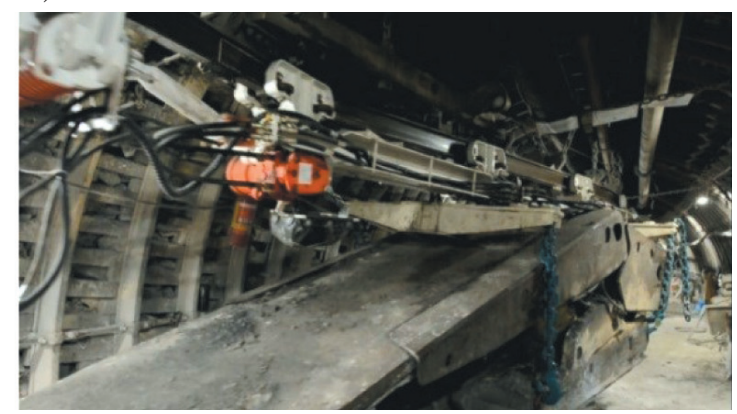

Fig. 8. Examples of design solutions of transportation sets: a) for personnel movement; b) for transportation of complete powered roof supports [5]

The use of diesel monorails required the development and implementation of new tracks as well as their suspensions. The basic requirement was to achieve the ability to transmit longitudinal force, which resulted in the development of new solutions for track connections. Numerous solutions for underground transportation including the transport of personnel (Fig. 8a), materials, and devices as well as face equipment, etc. was implemented. Transportation sets for an entire power roof support (Fig. 8b), significantly speeding up the relocation of mining systems, were worthy of special attention. The main advantages of using the diesel driven trains are as follows [6]:

- transport capacity not limited by length and branching of the route,

- ability to observe the route by the train driver,

- fast and easy elongation or shortening of the route,

- easy loading and unloading,

- ease of suspending different carriers,

- improving the effectiveness of transportation (transportation of machines and mining equipment in one piece) due to great pulling force,

- locomotive infinite variable travel speed change,

- ability to transport (which includes personnel) directly to the face,

- improvement of work safety due to installing the electronic control and blockade systems as well as intrinsically safe electrical installation.

The operation of the trains showed the following essential disadvantages in using the diesel drives in underground coal mine workings [7]:

- emission of gases and heat to the coal mines' surrounding environments,

- noise emission,

- necessity to transport fuel to underground workings, which requires high safety requirements (especially during refueling).

\section{INNOVATIVE SOLUTIONS OF SUSPENDED TRANSPORTATION DEVICES WITH BATTERY DRIVES}

The disadvantages of the operation of monorails with diesel drives mentioned in Chapter 2 were the reason for undertaking the realization of projects regarding the development of battery drives.

The development and setting to the operation of state-of-the-art energo-electronic equipment meeting the requirements for safe use in a potentially explosive atmosphere as well as battery packs was the criterial factor stimulating the further development of battery drives. In 1997, the Scharf company designed the first suspended monorail (EMTS type) with a battery drive intended for the movement of people and transportation of materials in ore mine workings without the threat of explosion hazards.

Using the experience gained, the BZ 45-2-40 battery-drive train for suspended monorails operating in hard coal mines underground was developed (Fig. 9).

A similar monorail of the DLZA 90F type (Fig. 10) was offered by Ferrit and Becker; Warkop developed and implemented the suspended CMA-190 batterydrive train (Fig. 11). Acid-lead batteries were used in these devices, which limited their application due to their heavy weight and large size (low energy density) that limited the functionality of these solutions.

The KOMAG Institute, in collaboration with other research organizations and industrial partners, developed innovative solutions of battery-driven suspended transportation machines intended for operation in potentially explosive atmosphere in mine undergrounds. These solutions are as follows: the "GAD-1 battery-drive train" and "PCA-1 suspended batterydrive train." 


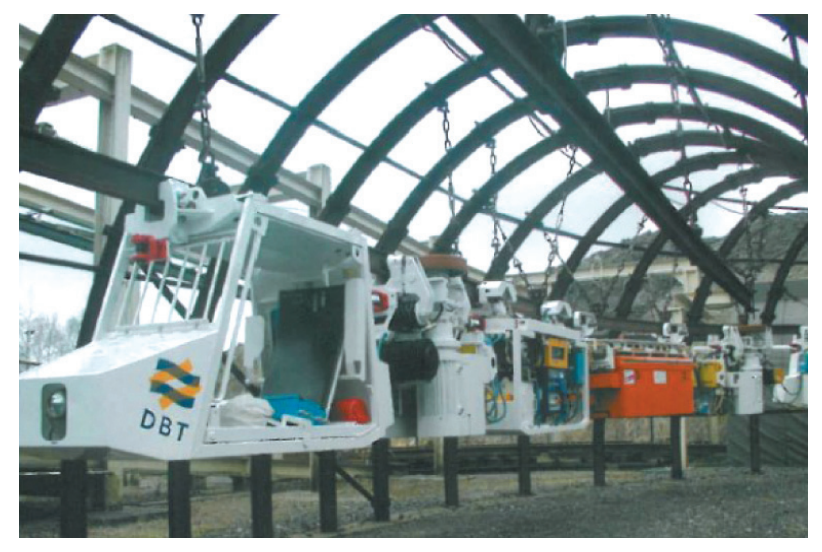

Fig. 9. Battery-driven monorail BZ 45-2-40 of Scharf Company [5]

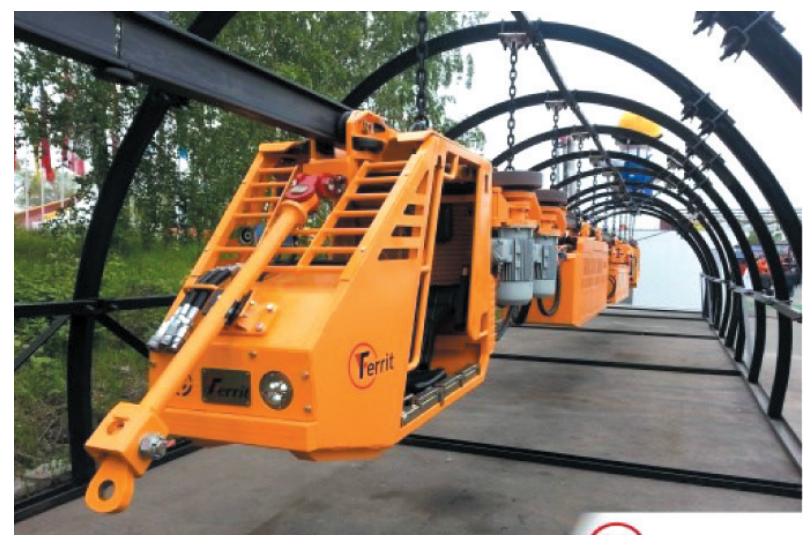

Fig. 10. DLZA 90F battery monorail made by Ferrit [5]
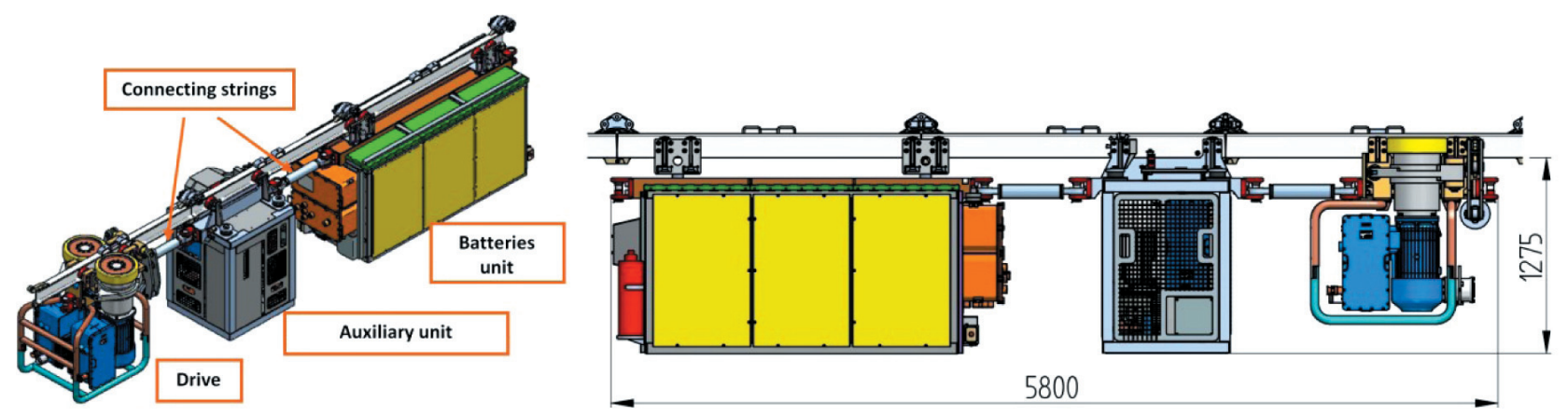

Fig. 11. Battery-driven CMA-1 drive train [5]

\subsection{GAD-1 suspended battery-drive train}

The GAD-1 battery-drive train (Fig. 12) adapted for suspended monorails is the result of the targeted project, the beneficiary of which was NAFRA Polska Sp. $z$ o.o. (the manufacturer). This solution was realized in collaboration with the Institute of Electrical Drives and Machines KOMEL as well as the following companies: IMPACT S.C., VACAT Sp. z o.o., SOMAR S.A., and ENEL-PC Sp. z o.o.

Lithium-polymer cells with high density of energy not used so far in the mining industry were used to

a)

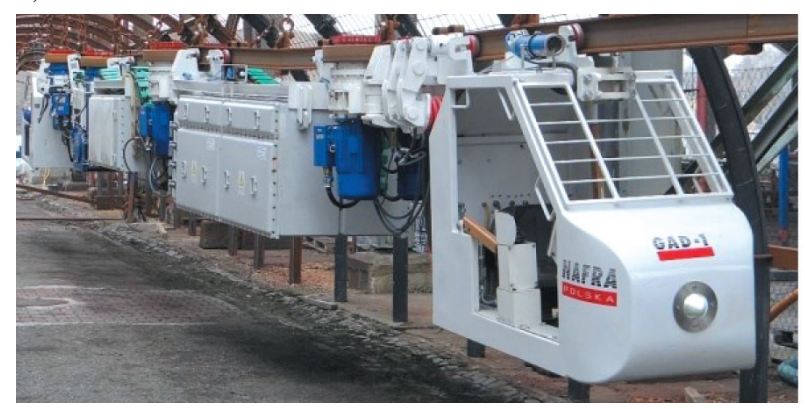

supply power to the drive train. Four units (each composed of 72 cells connected in series, making a battery with a total voltage of $265 \mathrm{~V} \mathrm{DC}$ ) were the source of power. A battery whose total energy equaled $160 \mathrm{kWh}$ was placed in a flame-proof casing.

Brushless synchronous motors with permanent magnets were used in the driving trolleys. Torque from the motors is transmitted in a frictional way and (in the case of inclinations over $10^{\circ}$ ) through a toothed gear (on a rack-and-pinion route). Sequential changes of the driving mode from a frictional to rack-and-pinion one and reverse is realized

b)

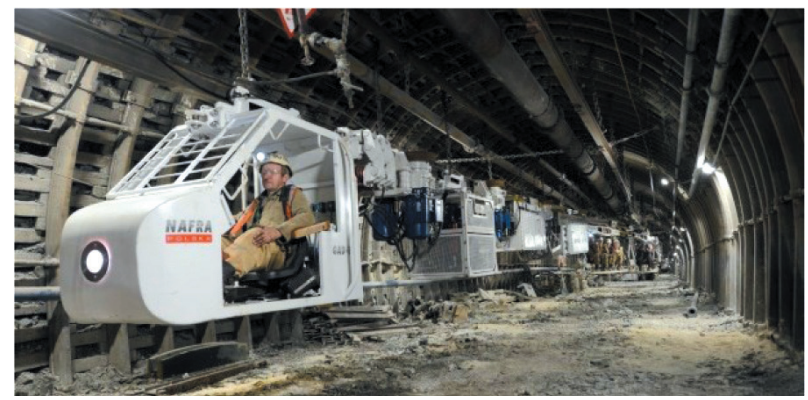

Fig. 12. GAD-1 suspended battery-drive train: a) at manufacturer stand; b) in underground working [8] 
sequentially by each driving trolley automatically. The mentioned motors have high efficiency compared to inductive motors, and they can be precisely controlled by a torque vector.

A master system for controlling the GAD-1 drive train was designed on the basis on a fuzzy logic structure connecting all of the components of the control system using the CAN network (which is resistant to any disturbances).

The versatility of the used CanOpen protocol enables communication among the subassemblies made by different manufacturers as well as diagnosing the CAN network.

The possibility of energy recovery during motor braking is a great advantage of the GAD-1 suspended drive train. An intelligent battery management system (BMS), which monitors the parameters of the battery set as well as each cell, is responsible for the energy recovery process, even deciding about the distribution of power between cells. Additionally, the system plays a protective role regarding both the software and hardware against unwanted situations, such as overcharging or the excessive discharging of the batteries.

The proper selection of parameters of the components cooperating with the battery set as well as the developed safety algorithms enabled the design of a machine intended for operation under conditions of combined hazards (methane and/or coal dust explosion, fire, water hazards). Fulfillment of the European requirements was confirmed by the EU-type examination certificate issued by the certifying body. Separate certificates for the main modules of the drive train (i.e., the MB-1pack of batteries, MZS-1 supply and control module, as well as ML-1 charging module) enabled their use in other applications in devices intended to be operated in a potentially explosive atmosphere.

\subsection{PCA-1 suspended battery-drive train}

Demand for the mechanization of operations of moving loads or machine components for relatively short distances (up to 100 meters) (e.g., in driven roadway fronts) was the reason for the development of the PCA-1 battery-drive train (Fig. 13). It can be optionally equipped with a transportation set with electrically driven hoists (Fig. 13, Point 5). There is also a possibility of using manually operated hoists or hoists supplied by other mediums from external sources in the transportation set.

The driving trolley (Fig. 13, Point 1) equipped with two frictional drive units with electric motors moves the transportation set along the suspended track.

The installed electromagnetic disk brakes play the roles of emergency and parking brakes. The battery, with a voltage of $48 \mathrm{~V} \mathrm{DC}$ and capacity of $100 \mathrm{Ah}$, is the source of power supply, and it consists of 15 highperformance lithium-iron-phosphate (LiFePO4) cells connected in series. It operates under the supervision of the BMS system and battery charge controller UMA-1. The change of direct current into alternating current (with adjustable frequency) is realized by the frequency inverter made by ENEL Sp. z o.o. All of the components of the electric equipment together with the battery cells and frequency inverter are installed in the MZ-1 power supply module, which consists of three chambers: equipment chamber, battery chamber, and connecting chamber. Its compact design enable a limitation of the number of electric
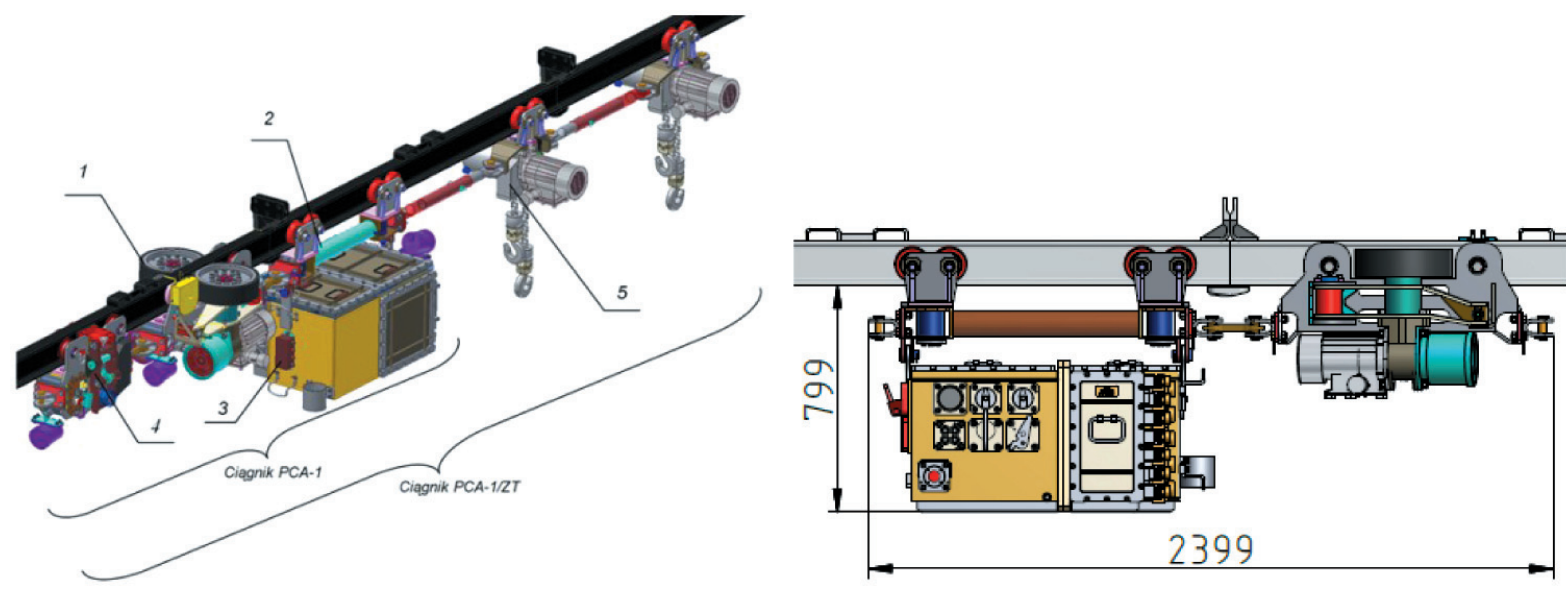

Fig. 13. PCA-1 suspended battery-drive train (PCA-1 - standard version, PCA-1/ZT - version with transportation set): 1 - driving trolley; 2 - battery trolley; 3 - supplying module; 4 - braking trolley; 5 - transportation set [8] 
equipment components (especially protective ones), which means the size and weight of the module are reduced. A wired control from the box connected to the MZ-1 module or a wireless (radio) control are possible. Micro-processor torque vector control in four quarters of the torque-speed system enables the operation with a recuperation of energy during braking by the electric motors and during lowering the load by electric hoists. The possibility of charging the batteries at the place of operation from the available transformer units is another innovation, which eliminates the necessity of moving the drive train to the depot. HELLFEIER Ltd. is the manufacturer of the PCA-1 drive train.

\section{COMPUTER TOOLS AIDING DESIGNERS AND USERS OF SUSPENDED TRANSPORTATION UNITS}

For ten years or so, the designing of the technical means for auxiliary mine transportation including suspended monorails with their own drives has been fully realized in the computer environment. The design process starts from the preparation of spatial geometrical models of the entire transportation system using the CAD (Computer-Aided Design) program environment. The transportation system consists of a transportation unit and suspended track. Depending on the configuration, the transportation unit usually consists of a drive train, carrying set, and system of braking trolleys. At this stage of the designing process, the main design assumptions such as required dimensions, weight, and detection of possible collisions between the spatial model parts and subassemblies are verified. An example of the geometric model of the GAD-1 suspended drive train with own drive (electric) is shown in Figure 14.

The method for analyzing the kinematics and dynamics of the Multi-Body System (MBS) enabling the calculation of dynamic forces during acceleration and braking (including emergency braking, both in the transportation unit as in the route's suspensions and connections) is used for the verification of the required assumed technical parameters of the future technical means in different criterial states. This is the repeatedly, statically indeterminate system.

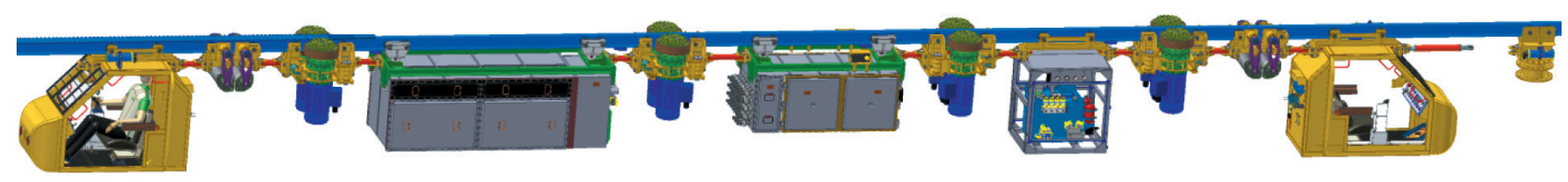

Fig. 14. Geometric model of mine suspended drive train prepared in CAD environment [8]

Initial geometrical models make the basis for the development of computational models, which consist of rigid and elastic bodies connected with different types of constraints (e.g., rotational, cylindrical, spherical, movable, and fixating ones). Apart from the constraints, the models of the contacts are applied. Advanced MBS class computer programs enable us to include the models of other subsystems of the drive transmission (e.g., chain gear) to the computational models. In Figure 15, an MBS computational model of the carrying unit for transporting of large-sized materials equipped with a complete system for lifting the longitudinal spreader beams is created in the MSC Adams computer program are shown. Computational models in the MBS program environment can be combined with other programs, making it possible to simulate the control systems. In such a way, the simulations of many stages of the transportation processes are conducted.

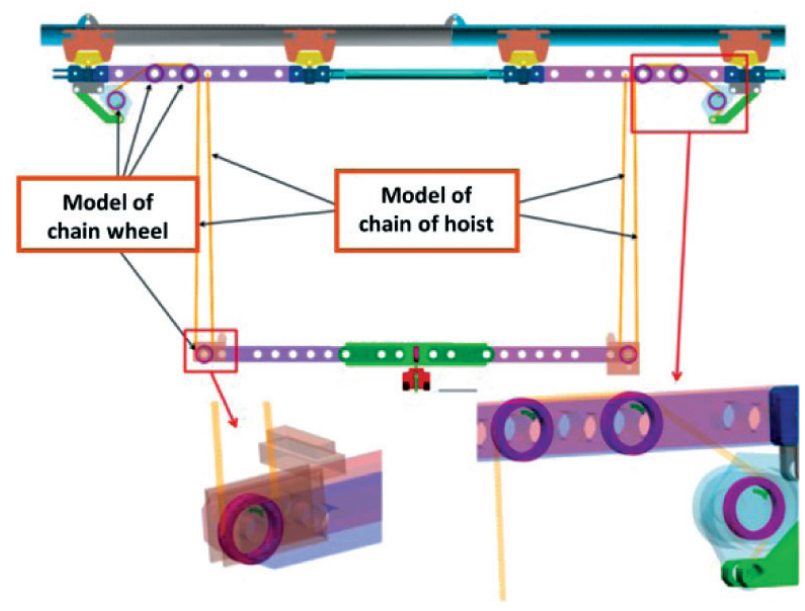

Fig. 15. Computational model of carrying unit created in environment of MBS computer program [9]

In the case of the carrying set, the stages are as follows: load lifting, its movement, and its descending. Examples of the force curves in the selected nodes 
of the carrying set during lifting the load, its stabilization, and then putting down on a floor is presented in Figure 16. The determination of force/time pro- cessing gives the possibility for identifying their maximum values in catches during the maneuvering of the transported load.

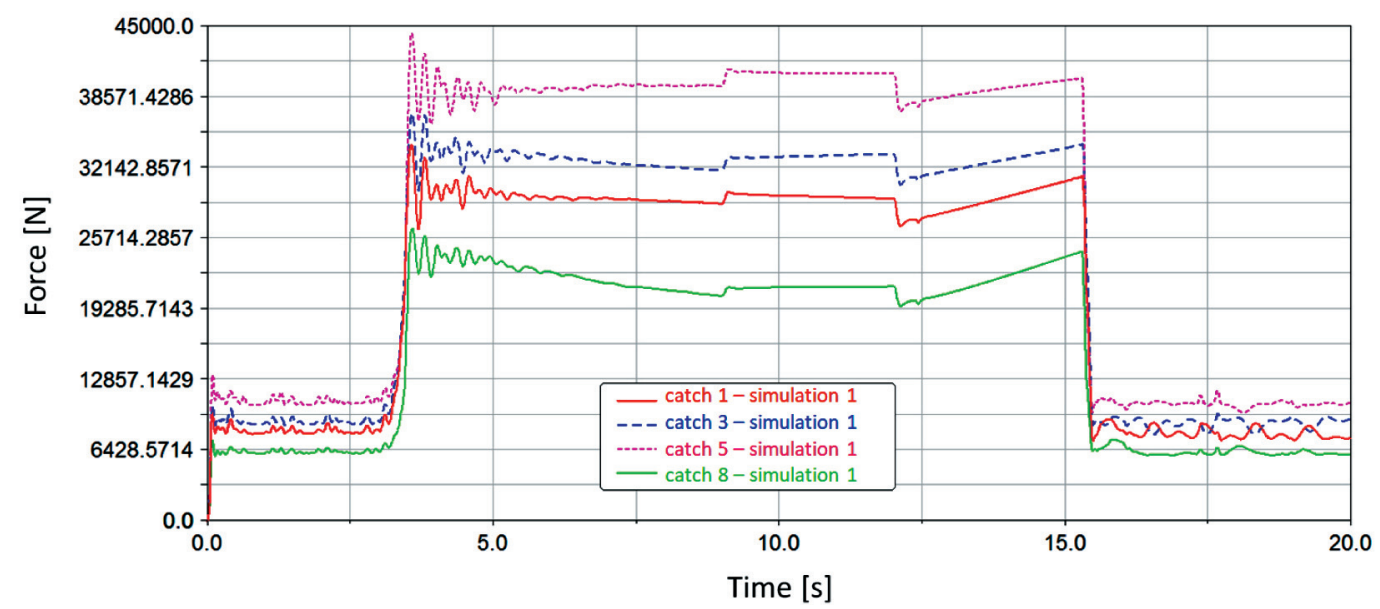

Fig. 16. Forces in carrying set during lifting large-size load and its descending [9]

The results of the MBS simulation are the input data for numerical analyses using the Finite Element Method. Besides the results presented above (force parameters), we can obtain information regarding the accelerations and decelerations acting on a technical mean (and at the same time on the operator) under so-called emergency conditions. Emergency conditions are usually associated with improperly used transportation means or its damage (e.g., traveling at speeds that are not allowed, using the brakes in the case of the transportation means' improper configuration, or hitting an obstacle). A sudden stop or change in travel direction can cause injuries to the operator and/or passengers. Identification of such a hazard requires special software for the simulation of rapid-changing phenomena. The computational models should include the models of anthropometric features, enabling the calculation of biomechanical parameters. These are the virtual equivalents of human dummies used in crash tests. In Figure 17, the effect of travel by suspended monorail with a speed of $5 \mathrm{~m} / \mathrm{s}$ on a bend of a radius equal to $4 \mathrm{~m}$ is presented.

Computer aiding not only includes the designing stage but is also used by suspended monorail users. According to the regulations of the Ministry of Energy of November 23, 2016, on the special requirements for transport operations in underground mining plants, the users of suspended transportation systems are obligated to make traction calculations. At the KOMAG Institute, the Safe Trans Design (STD) system enables the proper selection of transportation unit components (e.g., drive train, braking trolleys, carrying sets) for the required transportation conditions.
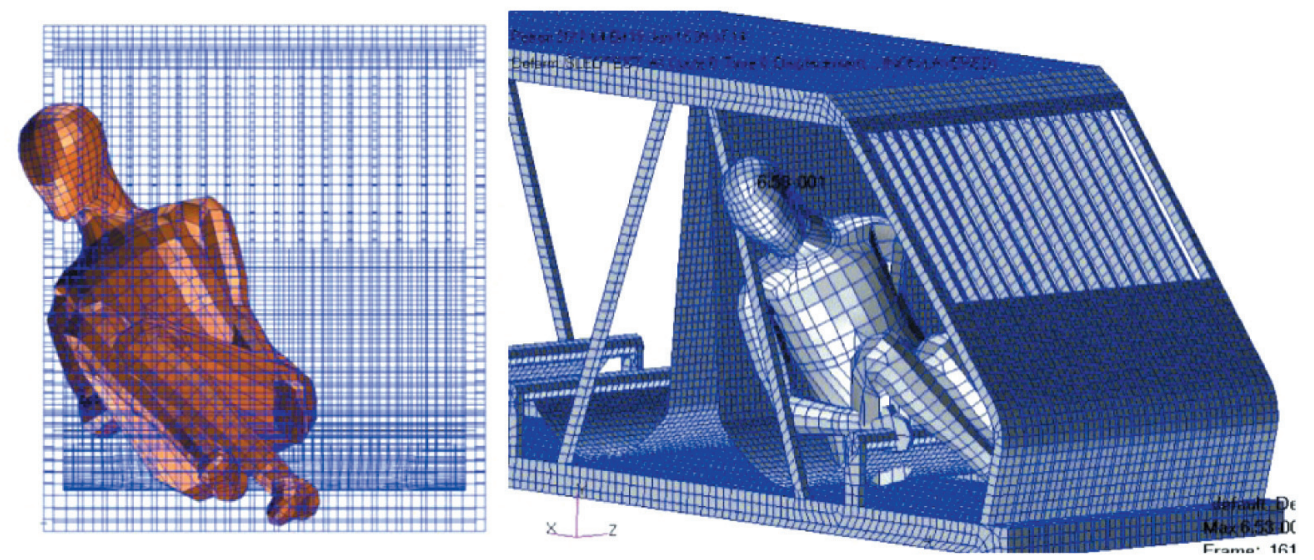

Fig. 17. Behaviour of virtual model of Hybrid III dummy during travel in cabin with speed of $5 \mathrm{~m} / \mathrm{s}$ on bend [10] 
In the case of a suspended monorail, these conditions are determined by the inclination of the roadway working in which materials are transported as well as the parameters of a suspended track (such as length, rail profile and type, as well as carrying capacity of the suspensions). The calculation results give us information about the maximum net weight of a transported load, braking distance, braking deceleration, distribution of longitudinal forces in the transportation set's strings, as well as enable us to perform a collision analysis in the case of transportation big-sized loads.

The STD system assists mining services in the preparation of documentation of the transporting system with suspended monorails to minimize errors during the configuration of suspended monorails as well as in traction calculations, which leads directly to improvements in work safety.

\section{PERSPECTIVE OF DEVELOPMENT OF SUSPENDED TRANSPORT}

Further development of the suspended rails in hard coal mines needs to be considered, taking the following aspects into account:

- mining-geologic conditions of current and future transport workings,

- parameters of transported loads (unit weight and size),

- safety level required for conducting transport operations,

- currently used means of transport, in the aspect of effectiveness,

- competitiveness of predicted new means of transport,

- minimization of effects to the environment,

- economic conditions - purpose and profitability of applying new means of transport.

Bearing in mind the borne investments, we can expect a radical replacement of diesel drives by battery drives. Thus, within a short period of time, we can expect:

- a reduction of emissions of harmful substances in exhaust gases,

- a reduction of emissions of noise and heat from diesel drive units.

In the near future, it is expected that ventilation conditions will force the implementation of electric drives. Thus, we will see further development of such drives; not only battery drives, but also those supplied from external source (e.g., from busbars).

The dynamic development of drives did not translate into an increase in track carrying capacity resulting from rail, rail connector strength parameters, and methods of suspending the transportation routes. Nominal loads of suspensions fixed to yielding support's arches due to the requirements of the current regulations is limited to $40 \mathrm{kN}$, which practically eliminates the transportation of bigger and heavier machines with the use of suspended monorails. An increase of load to the rail connectors is possible; e.g., in the result of using the spreader beams balancing load to the suspensions (Fig. 18).

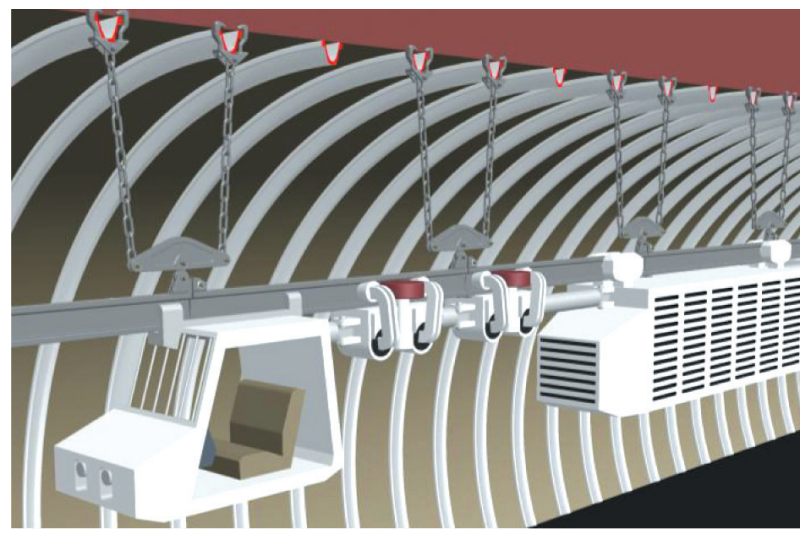

Fig. 18. Suspending transportation route on the support's arches with use spreader beam balancing load to suspensions (maximum load to rail connector towards suspension direction $80 \mathrm{kN}$ ) [11]

Methods for dynamic calculation (e.g., during railway braking - especially emergency braking) have not been developed so far. Development of the methods determining the dynamic forces in transportation route components is desired by both designers and users, especially in the aspect of possibilities for increasing the maximum speed of the railway (now $2 \mathrm{~m} / \mathrm{s}$ ). Thus, due to safety reasons, the specialists from the KOMAG Institute recorded the forces in the suspensions during braking in an underground roadway (including emergency braking) for a significantly reduced speed.

The fourth industry revolution (INDUSTRY 4.0) will incorporate automation, visualization, and monitoring systems to practical applications. In suspended monorails, we can expect the implementation of systems for travel control, enabling the current localization of the railway in a mine underground. Common use of RFID technology is also expected [12, 13]. 
The system will operate based on wireless data transmission, informing about the localization of transportation means as well as about their technical conditions. Software used for warning and alarming about emergency situations will be an important part of the system, contributing to the improvement of work safety on mine transportation routes.

\section{References}

[1] Mitrega J. (red.): Rozwój mechanizacji robót podziemnych w kopalniach węla kamiennego w PRL, Wydawnictwo Śląsk, Katowice 1967.

[2] Kovalik M.: Vykonnejsia viacdielna zavesna lokomotiva LZH-50. D.3, "Spravodaj" 1988, 1: 11-20.

[3] Marciniak Z., Jałmużna J.: Perspektywy rozwoju pomocniczego transportu podziemnego $w$ świetle oferty FMG "PIOMA" S.A., "Miesięcznik WUG" 2002, 3: 30-34.

[4] Pieczora E.: Prace prowadzone przez CMG KOMAG w zakresie dołowych i powierzchniowych waskotorowych lokomotyw spalinowych, Sympozjum nt. "Dołowe i powierzchniowe wąskotorowe lokomotywy spalinowe w kopalniach PW", CMG KOMAG, Gliwice 1990.

[5] Pieczora E., Suffner H.: Rozwój napędów dołowych kolejek podwieszonych, "Maszyny Górnicze" 2017, 3: 44-57.

[6] Fuksa D., Kęsek M., Ślósarz M., Bator A.: Koncepcja zintegrowanego systemu transportu poziomego $w$ kopalniach węgla kamiennego, "Przegląd Górniczy” 2015, 8: 23-25.
[7] Pieczora E.: Prognoza rozwoju szynowych systemów transportowych stosowanych $w$ podziemiach kopalń wegla kamiennego, "Gospodarka Surowcami Mineralnymi" 2008, 24, 1/2: 221-232.

[8] Pieczora E., Polnik B.: Nowe rozwiazania napędów elektrycznych do górniczych maszyn transportowych, "Cuprum" 2015, 3: 199-210.

[9] Szewerda K., Tokarczyk J., Turewicz A.: Metoda wyznaczania sit dynamicznych $w$ wysokoobciażalnych modułowych zestawach transportowych za pomoca analiz MBS, ITG KOMAG 2014, [unpublished].

[10] Tokarczyk J.: Wirtualne prototypowanie systemów mechanicznych $w$ górnictwie, ITG KOMAG 2014, [unpublished].

[11] Mrowiec H., Raszka W., Dyrda J.: Zawiesia torów jezdnych szynowych kolejek podwieszonych, Konferencja "Bezpieczeństwo pracy urządzeń transportowych w górnictwie", Centrum Badań i Dozoru Górnictwa Podziemnego, Ustroń 2010.

[12] Michalak D.: Applying the Augmented Reality and RFID Technologies in the Maintenance of Mining Machines, Proceedings of the World Congress on Engineering and Computer Science, San Francisco, USA 2012.

[13] Rogala-Rojek J., Jasiulek D., Latos M., Piecha A., Woszczyński M., Stankiewicz K.: iRIS - System identyfikacji maszyn, urzadzeń, środków trwałych oraz transportu, ITG KOMAG 2012, [unpublished].

EDWARD PIECZORA, Ph.D., Eng. JAROSEAW TOKARCZYK, Ph.D., Eng. KOMAG Institute of Mining Technology ul. Pszczyńska 37, 44-101 Gliwice, Poland \{epieczora,jtokarczyk\}@komag.eu 


\title{
Rozwój transportu podziemnego wykorzystującego kolejki podwieszone
}

\begin{abstract}
$W$ artykule przedstawiono rozwój jednoszynowych kolejek podwieszonych, wskazując na ich zalety oraz ograniczenia stosowania. Zwrócono uwagę na pojawienie się w ostatnich latach kolejek $z$ napędem akumulatorowym. Podano przykłady rozwiazań, w tym opracowanych w ITG KOMAG ciagników PCA-1 i GAD-1. Wskazano na rozwój narzędzi komputerowych wspomagajacych projektantów i użytkowników kolejek. Przedstawiono kierunki dalszego rozwoju transportu podwieszonego.
\end{abstract}

Słowa kluczowe: górnicze kolejki podwieszone, napęd linowy, napęd spalinowy, akumulatorowy, wirtualne prototypowanie, kierunki rozwoju

\section{WSTĘP}

Transport materiałów i urobku oraz przewóz ludzi jest jednym $z$ najważniejszych ogniw procesu wydobywczego zakładu górniczego. O ile transport po spągu jest stosowany od początku rozwoju górnictwa, a pierwsze tory kopalniane pojawiły się w XVII wie$\mathrm{ku}$, to początek zastosowania transportu podwieszonego nastąpił dopiero w połowie XX wieku. Do jego rozwoju przyczyniło się opracowanie nowoczesnych kołowrotów linowych, z zastosowaniem zamontowanej pod stropem wyrobiska liny (rys. 1), po której ręcznie lub za pomocą wciągarek przemieszczano wózki transportowe.

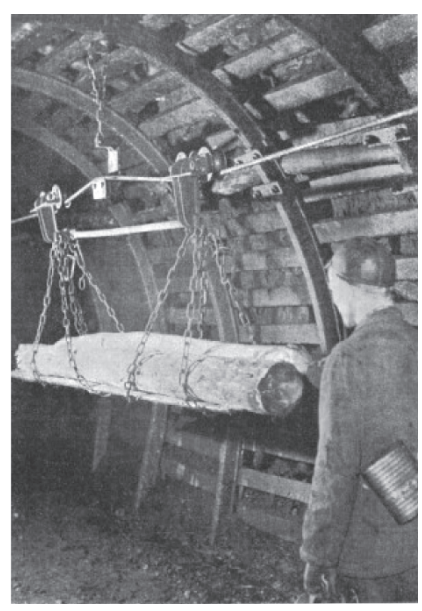

Rys. 1. Podwieszona kolej linowa [1]
W pierwszej połowie lat pięćdziesiątych $\mathrm{XX}$ wieku w Niemczech wprowadzono jako element nośny typową szynę kolei podziemnej (rys. 2), po której poruszały się wózki nośne ciągnięte przez linę, z masą ładunku dochodzącą do $1000 \mathrm{~kg}$ [2].

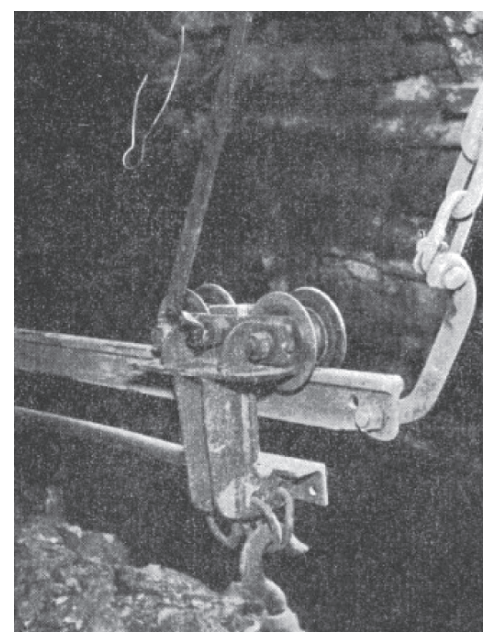

Rys. 2. Podwieszona kolej szynowa [1]

W 1956 roku niemiecka firma Scharf wdrożyła podwieszony dwuteownik jako element nośny toru do transportu z napędem linowym (rys. 3). Zestaw transportowy składał się z wózka ciągnącego, wózków transportowych z wciągnikami ręcznymi, kontenerów i wózka hamulcowego. System ten szybko rozpowszechnił się w kopalniach niemieckich, angielskich i francuskich [2]. 


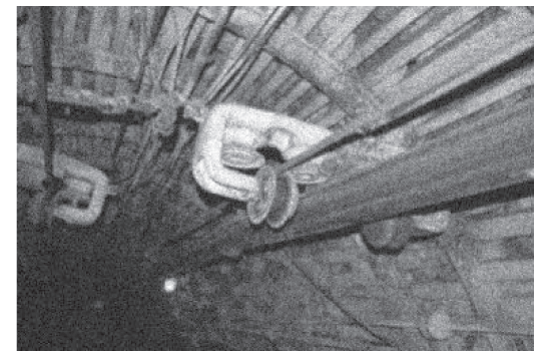

Rys. 3. Podwieszona kolej szynowa

(trasa dwuteownikowa) z napędem linowym [1]

Rozwój tego typu transportu w Europie Zachodniej był impulsem do podjęcia prac $\mathrm{w}$ tym zakresie również w KOMAG-u. Z początkiem lat sześćdziesiątych $\mathrm{XX}$ w. nawiązano współpracę KOMAG-u z FMG PIOMA, w wyniku której opracowano (na podstawie licencji firmy Becorit) i wdrożono do produkcji i stosowania w podziemiach kopalń kolejkę szynową z napędem linowym typu KSP-32 (przeznaczoną także do przewożenia ludzi), a następnie typu KSP-63. Stały się one szybko popularnymi dołowymi środkami transportu - przykładowo FMG PIOMA S.A. do 1992 r. wdrożyła 1200 kolejek typu KSP-32 [3]. Rozwój podwieszonych kolejek szynowych z napędem linowym skutkował zwiększeniem nośności i wytrzymałości jezdni szynowych oraz zespołów zestawu transportowego, a także zwiększeniem siły pociągowej napędów linowych. Doświadczenia eksploatacji kolejek z napędem linowym wskazały jednak na ich ograniczenia, tj.:

- możliwość prowadzenia transportu jedynie wzdłuż z góry wyznaczonej trasy,

- brak wizualnego kontaktu pracownika obsługującego napęd z zestawem transportowym,

- możliwość niekontrolowanego zerwania liny ciągnącej i stwarzającej zagrożenie wypadkowe,

- konieczne, stałe nakłady na konserwację liny oraz zespołów rolek prowadzących na trasie jezdnej.

Pod koniec lat sześćdziesiątych rozwój podwieszonego transportu linowego w Europie Zachodniej praktycznie został zakończony, natomiast w polskich kopalniach (stan na 31.12.2016 r.), według wiedzy autorów, eksploatowanych jest jeszcze 48 kolejek podwieszonych z napędem linowym. Napęd linowy zastąpiono mobilnymi urządzeniami trakcyjnymi - podwieszony ciągnik (lokomotywę) z napędem spalinowym (wysokoprężnym). Pierwsze, prototypowe rozwiązania firm angielskich zademonstrowano w 1965 r. Rynkowe zastosowanie zapoczątkowała firma Ruhrthaler z Niemiec, wprowadzając w 1967 r. do kopalń nie- mieckich i francuskich dwukabinowy ciągnik typu HL 32H. Kolejnymi rozwiązaniami, które pojawiły się na rynku, były ciągniki (lokomotywy) firmy Scharf z Niemiec oraz Stephanoise z Francji (1970 r.). W 1967 r. prace nad tego typu rozwiązaniem rozpoczęto w Czechosłowacji w Prievidzy (Bansky Vyskumny Ustav).

Wraz z rozwojem ciągników (lokomotyw) doskonalono trasy podwieszone, zwiększając nośność oraz poprawiając połączenie i zawieszenia. Zamiast profilu I 120 zaczęto powszechnie stosować profil I 140 wg DIN (I 155 wg PN), a obecnie stosowany jest także profil I 250. Udoskonalono również rozwiązania wózków nośnych i hamulcowych oraz zestawów transportowych, w tym wciągników [2].

\section{ROZWÓJ STOSOWANIA KOLEJEK PODWIESZONYCH \\ Z NAPĘDEM SPALINOWYM W POLSKICH KOPALNIACH WĘGLA KAMIENNEGO}

W 1976 roku w KOMAG-u opracowano pierwszą polską lokomotywę spalinową (ciągnik) Lps-80 do kolei podwieszonej, którą w 1979 r. wykonały Zakłady Urządzeń Naftowych i Gazowniczych w Krośnie. W latach 1979-1980 w KWK Ziemowit prowadzono jej próby doświadczalne, które pozwoliły na zebranie pierwszych doświadczeń eksploatacyjnych. Do napędu zastosowano silnik SW-400, wymagający okresowych regulacji ze względu na konieczność uzyskania wymaganej jakości (czystości) spalin. Silnik napędzał pompę RAUCHA o zmiennej wydajności $\left(0-10 \mathrm{dm}^{3} / \mathrm{min}\right)$ i ciśnieniu $20 \mathrm{MPa}$, a ta silniki hydrauliczne SW-160 produkcji firmy HYDROSTER. Układ oczyszczania i chłodzenia spalin zapewniał utrzymanie wymaganej temperatury gazów wylotowych poniżej $70^{\circ} \mathrm{C}$ [4].

Na podstawie doświadczeń z próbnej eksploatacji lokomotywy (ciągnika) Lps-80, w 1980 roku opracowano dokumentację prototypu lokomotywy podwieszonej spalinowej (ciągnika) Lps-90D (rys. 4). Do napędu zastosowano również ww. silnik spalinowy oraz sprawdzony układ zabezpieczeń, gwarantujący uzyskanie wymaganej czystości spalin, a także ich temperatury wylotowej. Zastosowano pompe typu PAG AZP250 firmy Rexroth z zabudowanym regulatorem stałej mocy oraz zdalnie (hydraulicznie) sterowanym regulatorem wydajności i kierunkiem przepływu oraz zespołem dwóch pomp zębatych. Pompa napędzała 


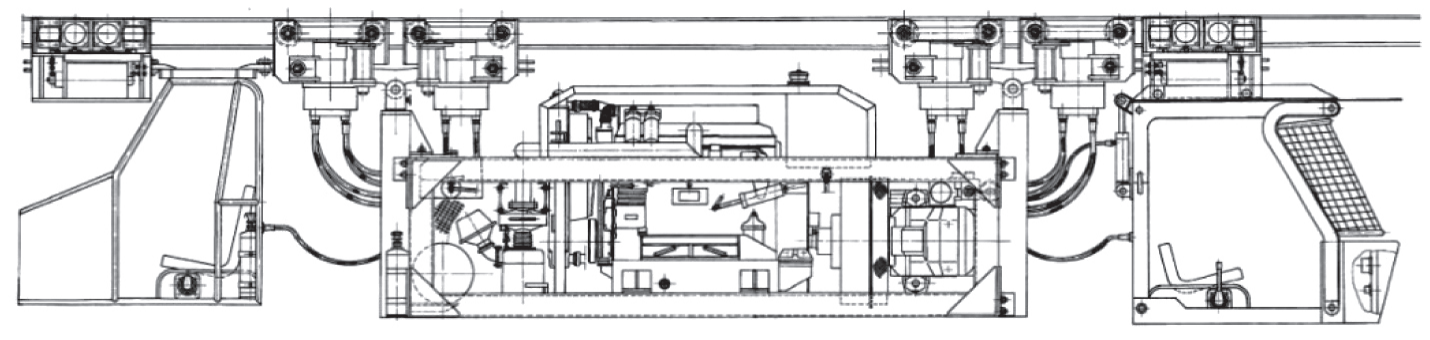

Rys. 4. Ciagnik podwieszony typu Lps-90D [4]

silniki hydrauliczne typu SOK-160K produkcji Hydroster. Wykonany w 1982 r. przez Zakład Naprawczy Taboru Samochodowego i Sprzętu w Brzesku (obecnie Małopolska Wytwórnia Maszyn Brzesko Sp. z o.o.) prototyp poddano próbom ruchowym w KWK Murcki, a następnie w KWK Piast, które potwierdziły poprawne działanie większości zespołów. Głównym mankamentem była niska trwałość wykładzin ciernych kół napędowych [4].

Powyższe doświadczenia wykorzystano podczas realizacji, w latach 1993-1996, wspólnie z FMG PIOMA S.A. (obecnie FAMUR S.A.), projektu celowego pt. "System transportu dołowego szynowymi kolejami podwieszonymi z napędem spalinowym". Opracowano, wykonano i przebadano, w warunkach stanowiskowych i ruchowych, lokomotywę (ciągnik spalinowy) o symbolu LPS-90 (rys. 5), przeznaczoną do napędu jednoszynowych kolei podwieszonych do transportu materiałów, elementów maszyn i urządzeń oraz do jazdy ludzi w podziemnych wyrobiskach górniczych potencjalnie zagrożonych wybuchem metanu i/lub pyłu węglowego.

Wyniki projektu przyczyniły się do późniejszego rozwoju kolejek podwieszonych z napędem spalinowym w FMG PIOMA S.A. (FAMUR S.A.) - rysunek 6.

a)

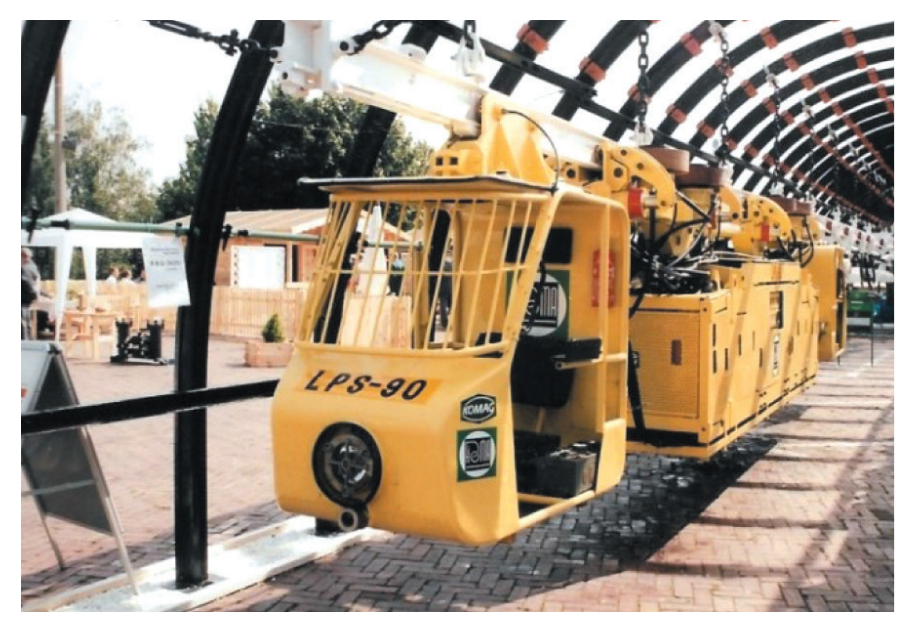

Wdrożenie kolei podwieszonych $\mathrm{z}$ napędem spalinowym $\mathrm{w}$ polskich kopalniach węgla kamiennego nastąpiło w pierwszej połowie lat dziewięćdziesiątych XX w. Na koniec 1995 r., w eksploatacji znajdowało się 35 tego typu urządzeń (KWK Ziemowit, KWK Piast, KWK Bogdanka - po 6 szt., KWK Mysłowice - 4 szt., KWK Wesoła, KWK Staszic - 3 szt., KWK Murcki, Czeczott - po 2 szt., KWK Brzeszcze, KWK Janina, KWK Andaluzja po 1 szt.). Były to kolejki firm: Ruhrthaler, Scharf, BVU Prievidza i ORTAS Pribram. Obecnie w polskich kopalniach (stan na 31.12.2016 r.), według wiedzy autorów, eksploatowanych jest 566 kolejek (ciągników) podwieszonych $\mathrm{z}$ napędem spalinowym. Głównymi ich dostawcami są firmy: BECKER-WARKOP Sp. z o.o., FAMUR S.A., SCHARF, BEVEX i FERRIT. Na rysunku 7 przedstawiono przykłady aktualnie oferowanych kolejek (ciągników) z napędem spalinowym, a w tabeli 1 ich podstawowe parametry.

Zastosowanie kolejek z napędem spalinowym wymagało opracowania i wdrożenia nowych tras jezdnych i ich zawiesi. Podstawowym wymogiem było przenoszenie siły wzdłużnej, skutkujące opracowaniem m.in. nowych rozwiązań połączenia szyn.

b)

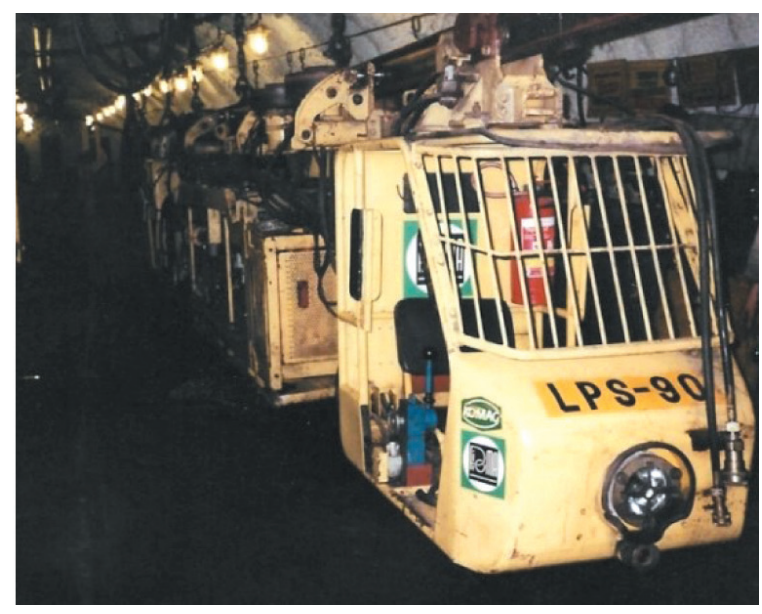

Rys. 5. Lokomotywa (ciagnik) LPS-90: a) na targach KATOWICE’ 95; b) w wyrobisku podziemnym [5] 




Rys. 6. Rozwój kolei z napędem spalinowym w FMG PIOMA S.A./FAMUR S.A [5]

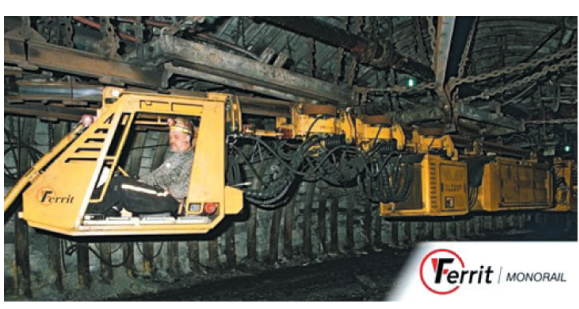

Kolejki DLZ110F i DLZ210F firmy Ferrit

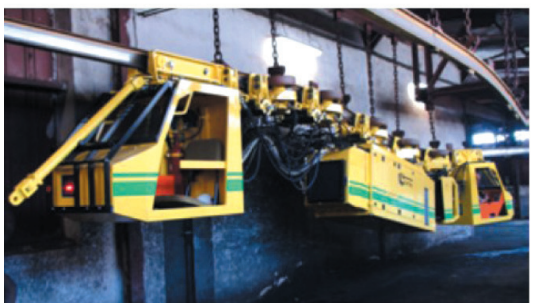

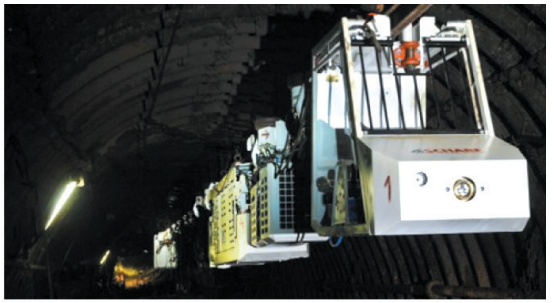

Kolejki DZ 80 firmy Scharf

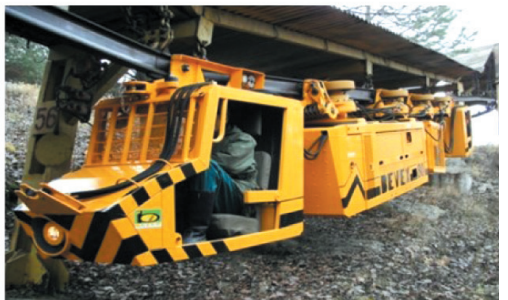

Rys. 7. Przykłady aktualnie oferowanych kolejek z napędem spalinowym [5]

Tabela 1

Podstawowe dane wybranych kolejek z napędem spalinowym [5]

\begin{tabular}{|c|c|c|c|c|c|c|c|}
\hline Тур & $\begin{array}{l}\text { Produ- } \\
\text { cent }\end{array}$ & $\begin{array}{c}\text { Max. sila } \\
\text { uciągu } \\
{[\mathrm{kN}]}\end{array}$ & $\begin{array}{c}\text { Liczba } \\
\text { wózków } \\
\text { napędowych }\end{array}$ & $\begin{array}{c}\text { Max. } \\
\text { prędkość } \\
{[\mathbf{m} / \mathbf{s}]}\end{array}$ & $\begin{array}{c}\text { Max. } \\
\text { nachylenie } \\
{\left[{ }^{\circ}\right]}\end{array}$ & $\begin{array}{c}\text { Moc silnika } \\
\text { spalinowego } \\
{[\mathrm{kW}]}\end{array}$ & $\begin{array}{c}\text { Producent } \\
\text { silnika } \\
\text { spalinowego }\end{array}$ \\
\hline KP-95 & $\begin{array}{l}\text { Becker- } \\
\text { Warkop }\end{array}$ & $40-240$ & $2-12$ & 2,5 & 30 & $80-95$ & Deutz \\
\hline KP-96 & $\begin{array}{l}\text { Becker- } \\
\text { Warkop }\end{array}$ & $40-240$ & $2-12$ & 2,5 & 30 & 96 & Perkins \\
\hline KP-148 & $\begin{array}{l}\text { Becker- } \\
\text { Warkop }\end{array}$ & $40-240$ & $2-12$ & 2,5 & 30 & 148 & Deutz \\
\hline FMS & Famur & $85 / 105 / 120 / 140$ & $4 / 5 / 6 / 7$ & 2,5 & 30 & 81 lub 95 & Deutz \\
\hline $\mathrm{CSZ}$ & Famur & $85 / 105 / 120 / 140$ & $4 / 5 / 6 / 7$ & 2,6 & 30 & 123 & Deutz \\
\hline DZ 80 & Scharf & 160 & $3-8$ & 2 & 30 & 80 & Liebherr \\
\hline DZ 130 & Scharf & 160 & $3-8$ & 2,5 & 30 & 130 & Liebherr \\
\hline DLZ 110F & Ferrit & $60-140$ & $4-7$ & 2,0 & 30 & 81 & Zetor \\
\hline DLZ 210F & Ferrit & $110-330$ & $4-12$ & 3,1 & 30 & $127-142$ & John Deere \\
\hline LZH120D5.1 & Ortas & $80 / 100 / 120$ & $4 / 5 / 6$ & $2,0 / 1,7 / 1,4$ & 30 & 81 & Zetor \\
\hline BEVEX 80 & Bevex & $60 / 80 / 100$ & $3 / 4 / 5$ & $2,0 / 1,8 / 1,5$ & 25 & 81 & - \\
\hline BEVEX 90 & Bevex & $80 / 100 / 120$ & $4 / 5 / 6$ & $2,0 / 1,8 / 1,5$ & 30 & 91 & - \\
\hline
\end{tabular}


a)

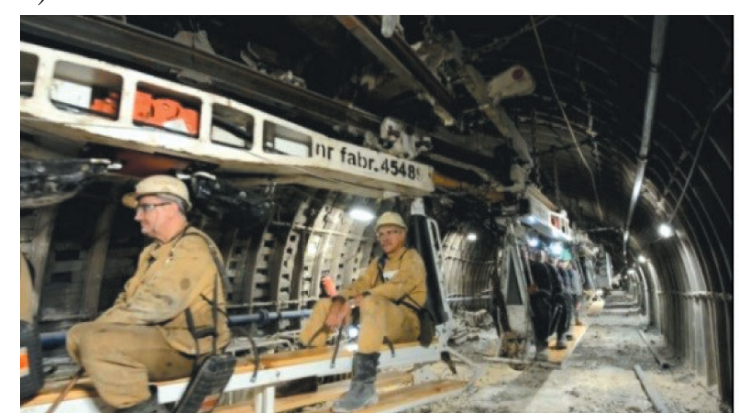

b)



Rys. 8. Przykładowe rozwiazania zestawów transportowych: a) do jazdy ludzi; b) do transportu kompletnych sekcji obudowy zmechanizowanej [5]

Wdrożono liczne rozwiązania zestawów transportowych, w tym do jazdy ludzi (rys. 8a), transportowania materiałów i urządzeń, wyposażenia przodków chodnikowych itd. Na szczególną uwagę zasługują zestawy do transportu kompletnych sekcji obudowy zmechanizowanej (rys. 8b), umożliwiające znaczne skrócenie czasu relokacji kompleksów ścianowych.

Główne zalety stosowania kolejek z napędem spalinowym to [6]:

- możliwość transportu po nieograniczonej długości i rozgałęzionej trasie,

- możliwość ciągłej obserwacji trasy przez maszynistę,

- łatwe i szybkie wydłużanie lub skracanie trasy,

- łatwy załadunek i wyładunek,

- łatwość podwieszania różnych nośników,

- zwiększenie efektywności transportu (przewożenie maszyn i urządzeń górniczych w całości) dzięki dużej sile uciągu,

- bezstopniowa zmiana prędkości jazdy lokomotywy,

- możliwość transportowania (w tym dowozu załogi) bezpośrednio do przodka,

- poprawa bezpieczeństwa pracy dzięki zastosowaniu elektronicznego systemu kontroli i blokad oraz przeciwwybuchowej instalacji elektrycznej.

Eksploatacja kolejek ujawniła również następujące zasadnicze niedogodności stosowania napędów spalinowych w podziemnych wyrobiskach kopalń węgla kamiennego [7]:

- emisja spalin i ciepła do otaczającej atmosfery kopalnianej,

- generowanie hałasu,

- konieczność transportu paliwa do podziemnych wyrobisk przy spełnieniu wysokich wymagań bezpieczeństwa, zwłaszcza podczas tankowania.

\section{INNOWACYJNE ROZWIAZANIA PODWIESZONYCH URZACDZEŃ TRANSPORTOWYCH Z NAPĘDEM AKUMULATOROWYM}

Wymienione w rozdziale 2 ograniczenia stosowania kolejek z napędem spalinowym przyczyniły się do podjęcia prac nad powstaniem napędu akumulatorowego.

Kryterialnym czynnikiem, stymulującym rozwój napędu akumulatorowego, było opracowanie i uruchomienie nowoczesnej aparatury energoelektronicznej spełniającej wymogi bezpiecznego stosowania w atmosferach potencjalnie wybuchowych oraz baterii akumulatorów. W 1997 r. firma Scharf opracowała pierwszą kolejkę podwieszoną (typu EMTS) z napędem akumulatorowym, przeznaczoną do przewozu osób i transportu materiałów w niezagrożonych wybuchem wyrobiskach kopalń rud.

Korzystając z nabytych doświadczeń, opracowano ciągnik akumulatorowy typu BZ 45-2-40 (rys. 9) do kolejek podwieszonych eksploatowanych w podziemnych wyrobiskach kopalń węgla kamiennego.

Podobną kolejkę, typu DLZA 90F (rys. 10), zaoferowała firma Ferrit, zaś firma Becker - Warkop opracowała i wdrożyła podwieszony ciągnik akumulatorowy CMA-190 (rys. 11). W urządzeniach tych zastosowano baterie kwasowo-ołowiowe, których duża masa i wymiary (niska gęstość energii) ograniczają funkcjonalność wymienionych rozwiązań.

Również Instytut KOMAG, przy współpracy z innymi jednostkami oraz partnerami przemysłowymi, opracował innowacyjne rozwiązania podwieszonych urządzeń transportowych, zasilane z baterii akumulatorowych, przeznaczone do eksploatacji w podziemnych wyrobiskach górniczych potencjalnie zagrożonych wybuchem. Są to: Ciagnik akumulatorowy GAD-1 i Podwieszony ciagnik akumulatorowy PCA-1. 


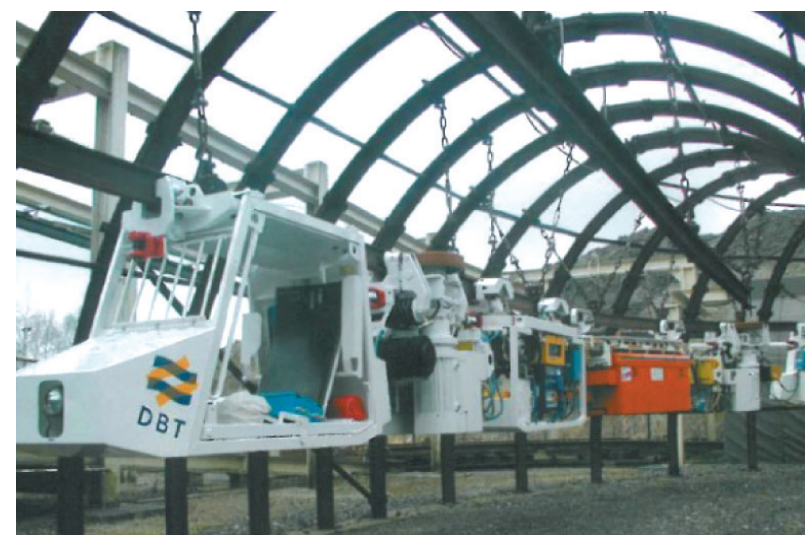

Rys. 9. Kolejka akumulatorowa typu BZ 45-2-40 firmy Scharf [5]

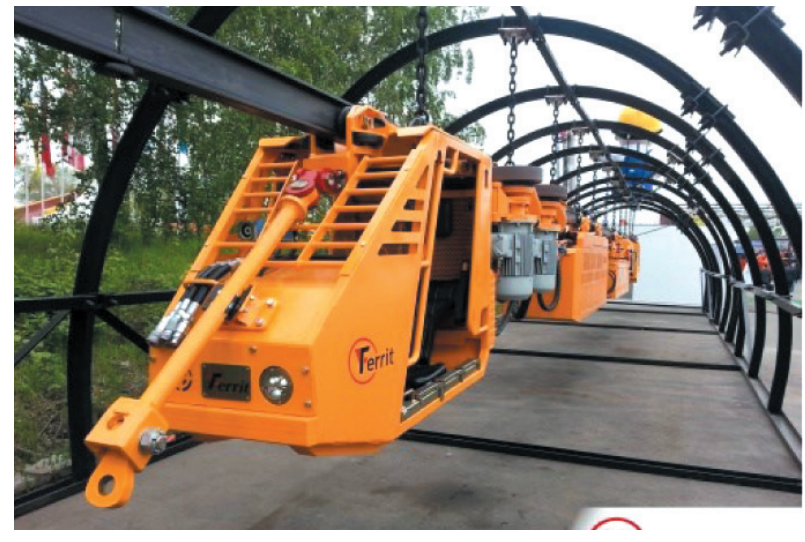

Rys. 10. Kolejka akumulatorowa typu DLZA $90 F$ firmy Ferrit [5]
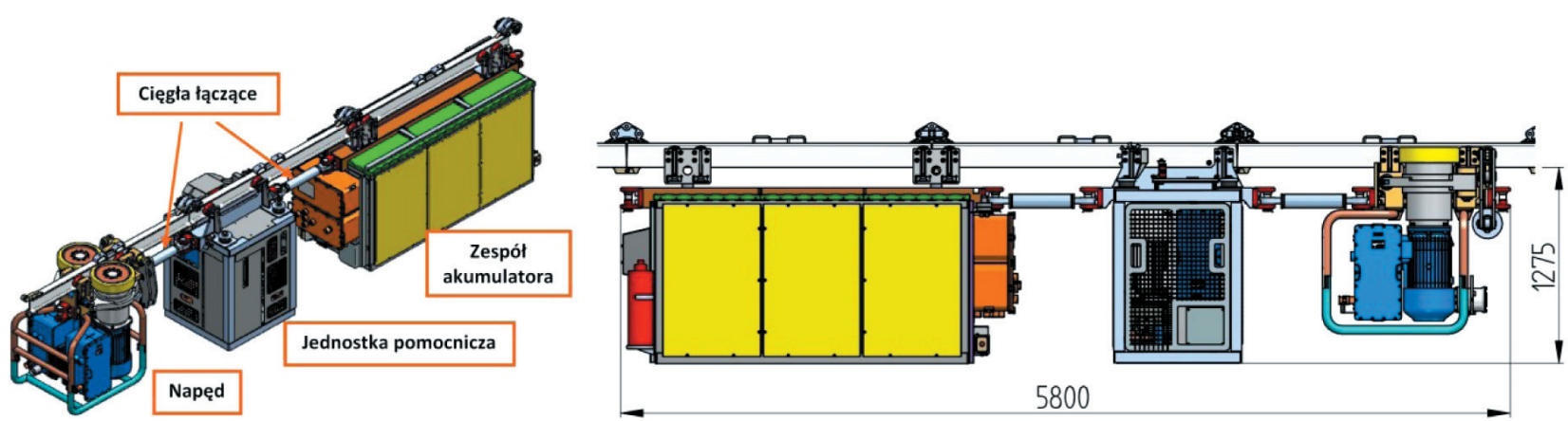

Rys. 11. Ciagnik manewrowy akumulatorowy CMA-1 [5]

\subsection{Podwieszony ciągnik akumulatorowy GAD-1}

Ciągnik akumulatorowy GAD-1 (rys. 12), przeznaczony do kolejek podwieszonych, jest efektem realizacji, projektu celowego, którego beneficjentem była firma NAFRA Polska Sp. z o.o. (producent). Rozwiązanie powstało przy współpracy z Instytutem Napędów i Maszyn Elektrycznych KOMEL oraz firmami IMPACT S.C., VACAT Sp. z o.o., SOMAR S.A. i ENEL-PC Sp. z o.o.

Do zasilania napędu ciągnika zastosowano ogniwa litowo-polimerowe, o dużej gęstości energii, niewyko-

a)

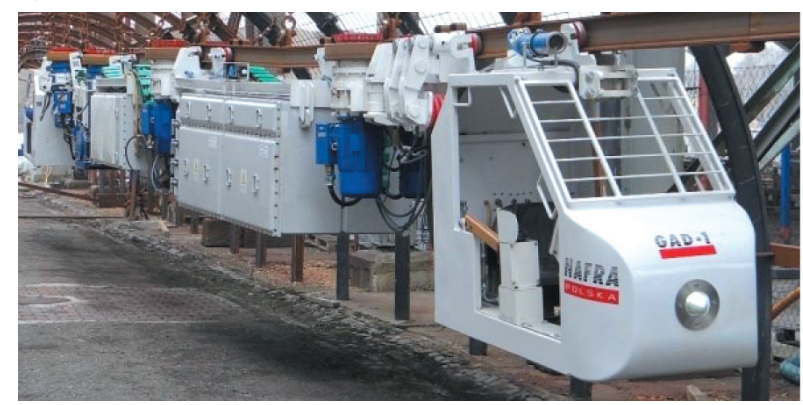

rzystywane do tej pory w górnictwie. Źródłem zasilania są cztery zespoły, każdy z szeregowo połączonych ze sobą 72 ogniw, tworzących baterię o napięciu 265 VDC. Baterię, o łącznej energii 160 kWh, umieszczono w osłonie ognioszczelnej.

W wózkach napędowych zastosowano bezszczotkowe silniki synchroniczne $\mathrm{z}$ magnesami trwałymi. Moment obrotowy z silników jest przenoszony na trasę jezdną w sposób cierny, a przy nachyleniach powyżej $10^{\circ}$ - przez przełożenie zębate (po trasie zębatej). Sekwencyjna zmiana trybu napędowego z ciernego na zębaty i odwrotnie, kolejno, przez poszczególne

b)

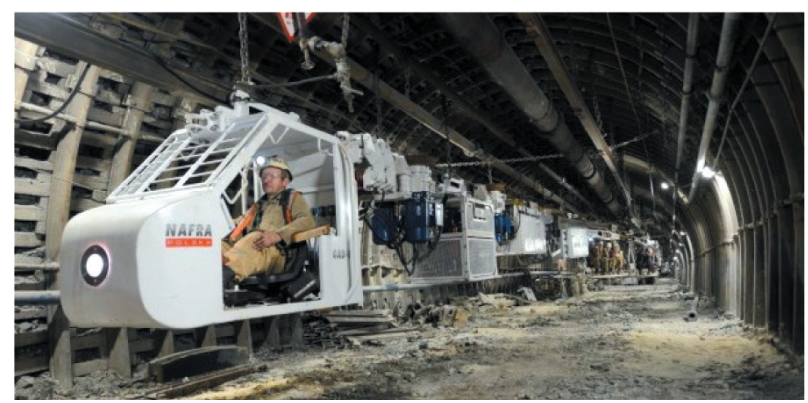

Rys. 12. Podwieszony ciagnik akumulatorowy GAD-1: a) na stanowisku producenta; b) w wyrobisku podziemnym [8] 
wózki napędowe, realizowana jest automatycznie. Wymienione silniki cechuje wysoka sprawność (w porównaniu z silnikami indukcyjnymi) i bardzo precyzyjne sterowanie wektorem momentu.

Nadrzędny system sterowania ciągnikiem GAD-1 zbudowano na podstawie struktury rozproszonej, łączącej ze sobą wszystkie elementy układu sterowania za pośrednictwem magistrali CAN, cechującej się wysoką odpornością na zakłócenia.

Uniwersalność zastosowanego protokołu CanOpen pozwala na komunikowanie się podzespołów różnych producentów oraz umożliwia diagnozowanie magistrali.

Atutem podwieszonego ciągnika GAD-1 jest możliwość rekuperacji energii podczas hamowania silnikami. Za poprawność działania tego procesu odpowiada inteligentny system nadzoru zespołem baterii BMS, który służy do ciągłego monitoringu parametrów zarówno całego zespołu baterii, jak i każdego ogniwa indywidualnie, decydując o równomiernym rozpływie energii pomiędzy poszczególnymi ogniwami. Dodatkowo, pełni funkcję zabezpieczenia, zarówno programowego, jak i sprzętowego, przed niepożądanymi zdarzeniami, takimi jak przeładowanie czy nadmierne rozładowanie baterii.

Odpowiedni dobór parametrów komponentów współpracujących z zespołem baterii oraz opracowane algorytmy bezpieczeństwa pozwoliły na opracowanie maszyny przeznaczonej do pracy w warunkach zagrożeń skojarzonych (zagrożenie wybuchem metanu i/lub pyłu węglowego, pożarowe, wodne). Spełnienie wymagań unijnych potwierdzono wydaniem certyfikatów badania typu WE przez jednostkę notyfikowaną. Odrębne certyfikaty, obejmujące podstawowe moduły ciągnika, tj. baterii akumulatorów MB-1, moduł zasilająco-sterujący MZS-1 i moduł ładujący MŁ-1, pozwalają na ich niezależną implementację w innych urządzeniach przeznaczonych do eksploatacji w atmosferach potencjalnie wybuchowych.

\subsection{Podwieszony ciągnik akumulatorowy PCA-1}

Potrzeba mechanizacji prac związanych z przemieszczaniem ładunków lub elementów maszyn na stosunkowo krótkich odległościach (do $100 \mathrm{~m}$ ), np. w drążonych przodkach chodnikowych, stanowiła podstawę opracowania podwieszonego ciągnika akumulatorowego PCA-1 (rys. 13). Może on być opcjonalnie wyposażony $\mathrm{w}$ zestaw transportowy $\mathrm{z}$ wciągnikami z napędem elektrycznym (rys. 13, poz. 5). Istnieje również możliwość zastosowania, w zestawie transportowym, wciągników z napędem ręcznym lub zasilanych innym medium, z zewnętrznego źródła.

Do przemieszczania zestawu transportowego po jezdni podwieszonej służy wózek napędowy (rys. 13, poz. 1), wyposażony w dwa zespoły napędu ciernego z silnikami elektrycznymi.

Zabudowane w nich tarczowe hamulce elektromagnetyczne pełnią funkcję hamulca postojowego i awaryjnego. Źródłem zasilania jest bateria o napięciu 48 VDC i pojemności $100 \mathrm{Ah}$, składająca się z połączonych szeregowo 15 wysokowydajnych ogniw litowo-żelazowo-fosfatowych (LiFePO4). Pracuje ona pod nadzorem systemu BMS oraz kontrolera stanu naładowania baterii UMA-1. Zamiana prądu stałego na prąd przemienny, o regulowanej częstotliwości, realizowana jest przez falownik wykonywany przez firme ENEL Sp. z o.o. Wszystkie elementy wyposażenia
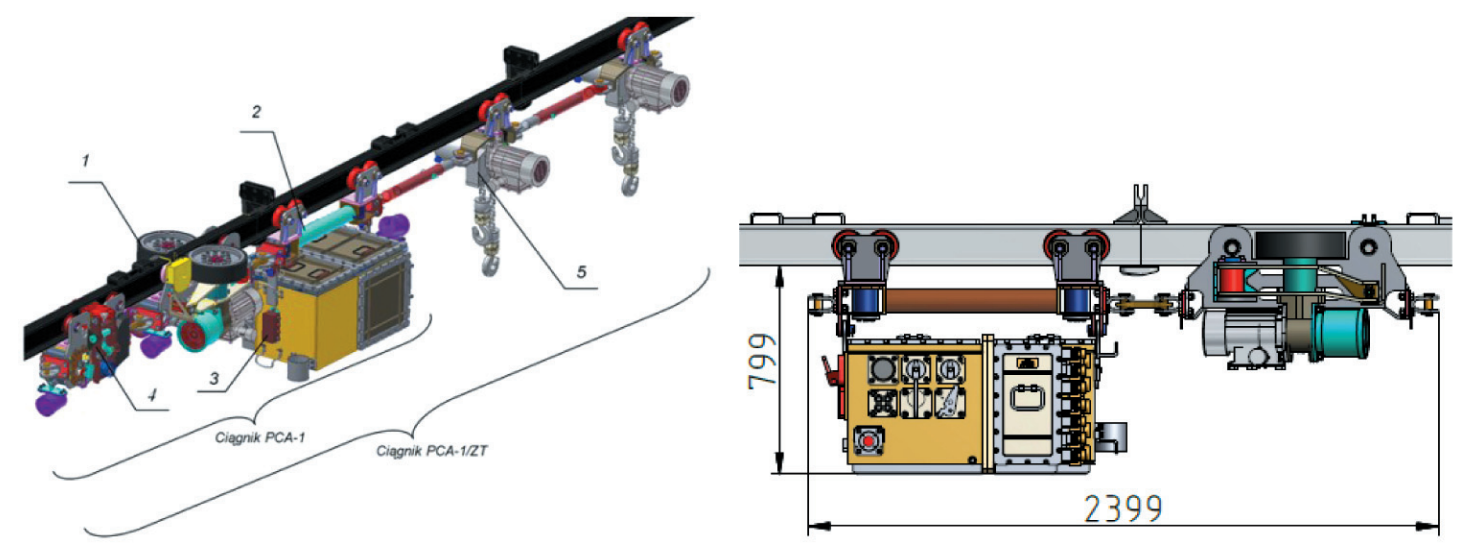

Rys. 13. Podwieszony ciagnik akumulatorowy PCA-1 (PCA-1 - wersja standardowa, PCA-1/ZT wersja z zestawem transportowym): 1 - wózek napędowy, 2 - wózek aparaturowy, 3 - modut zasilajacy, 4 - wózek hamujący, 5 - zestaw transportowy [8] 
elektrycznego wraz z baterią ogniw i falownikiem zabudowano w module zasilającym MZ-1, składającym się z trzech komór: aparaturowej, akumulatorowej i przyłączeniowej. Kompaktowa konstrukcja pozwoliła na ograniczenie liczby elementów aparatury elektrycznej (zwłaszcza zabezpieczającej), a tym samym ograniczenie gabarytów modułu oraz jego masy. Przewidziano możliwość sterowania przewodowego, z kasety połączonej z modułem MZ-1, lub bezprzewodowego (radiowego). Mikroprocesorowe sterowanie wektorem momentu w czterech ćwiartkach układu moment - prędkość, umożliwia pracę z rekuperacją energii w czasie hamowania silnikami elektrycznymi, a także podczas opuszczania mas elektrycznymi wciagnikami. Kolejną, innowacyjną cechą rozwiązania jest możliwość doładowywania baterii $\mathrm{w}$ miejscu eksploatacji, z ogólnodostępnych zespołów transformatorowych, co eliminuje potrzebę przemieszczania ciagnika do zajezdni. Producentem ciągnika PCA-1 jest firma HELLFEIER Sp. z o.o.

\section{KOMPUTEROWE NARZĘDZIA WSPOMAGAJACE PROJEKTANTÓW I UŻYTKOWNIKÓW TRANSPORTU PODWIESZONEGO}

Od kilkunastu lat proces projektowania środków technicznych pomocniczego transportu górniczego, w tym kolejek podwieszonych z napędem własnym, jest realizowany wyłącznie w środowisku komputerowym. Proces projektowania rozpoczyna się od opracowywania przestrzennych modeli geometrycznych, obejmujących cały system transportowy za pomocą programów klasy CAD (Computer Aided Design). W skład systemu transportu podwieszonego wchodzi zespół transportowy oraz trasa podwieszona. Kompletny zespół transportowy w zależności od konfiguracji, jest najczęściej zbudowany z ciągnika, zestawu nośnego oraz układu wózków hamulcowych. $\mathrm{Na}$ tym etapie procesu projektowego weryfikowane są podstawowe założenia, takie jak: wymagane gabaryty zewnętrzne, masa oraz wykrywanie kolizyjności pomiędzy częściami i zespołami modelu przestrzennego. Przykład modelu geometrycznego ciągnika podwieszonego GAD-1 z napędem własnym (elektrycznym) przedstawiono na rysunku 14.

Do weryfikacji założonych i wymaganych parametrów technicznych przyszłego środka technicznego, w różnych stanach kryterialnych stosowana jest metoda analizy kinematyki i dynamiki układów wieloczłonowych MBS (Multi-Body System), umożliwiająca obliczenie wartości sił dynamicznych podczas rozpędzania i hamowania, w tym hamowania awaryjnego, występujących zarówno w zespole transportowym, jak i w złączach i zawiesiach trasy podwieszonej. Jest to układ wielokrotnie, statycznie niewyznaczalny.

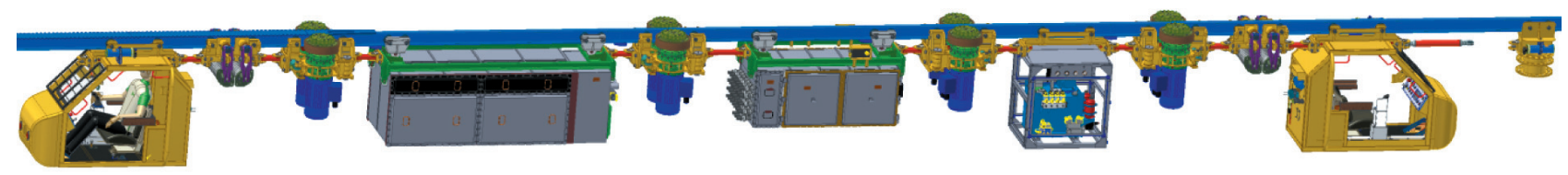

Rys. 14. Model geometryczny ciagnika górniczej kolejki podwieszonej opracowany w środowisku oprogramowania klasy CAD [8]

Wstępne modele geometryczne stanowią podstawę do opracowania modeli obliczeniowych, które składają się ze sztywnych lub podatnych brył, połączonych odpowiednimi więzami różnych klas, np. obrotowymi, cylindrycznymi, sferycznymi, przesuwnymi i utwierdzającymi. Oprócz więzów stosowane są modele kontaktów. Zaawansowane programy klasy MBS umożliwiają wprowadzenie do modeli obliczeniowych modeli innych podukładów przeniesienia napędu, np. przekładni łańcuchowej. Na rysunku 15 przedstawiono model obliczeniowy zestawu nośnego do transportu materiałów wielkogabarytowych z kompletnym układem podnoszenia trawers wzdłużnych, utworzony w środowisku programu MSC.Adams.

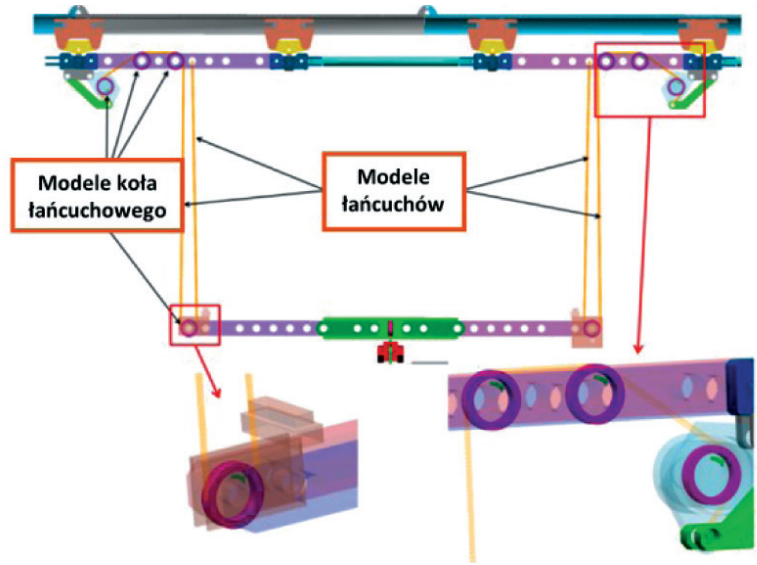

Rys. 15. Model obliczeniowy modutowego zestawu nośnego, utworzony $w$ środowisku programu klasy MBS [9] 
Modele obliczeniowe, w programach klasy MBS mogą być sprzęgane z programami, w których możliwe jest symulowanie układów sterowania. W ten sposób prowadzone są symulacje wielu faz procesu transportu. W przypadku zestawu nośnego może to być cykl: podnoszenie ładunku, przejazd i jego opuszczenie. Na rysun- ku 16 przedstawiono przykładowy przebieg sił w wybranych węzłach zestawu nośnego podczas podnoszenia ładunku, jego ustabilizowania się, a następnie opuszczenia na spąg. Wyznaczenie przebiegów sił daje możliwość identyfikacji wartości maksymalnych w zaczepach podczas manewrowania transportowanym ładunkiem.

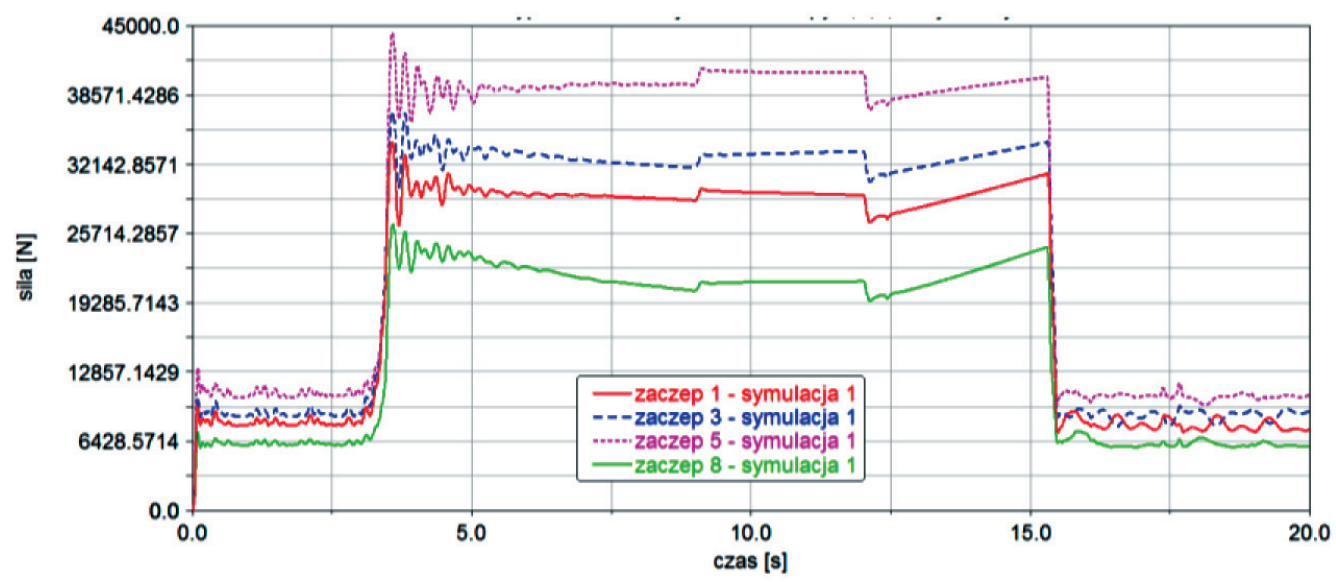

Rys. 16. Przebieg sił w zestawie nośnym podczas podnoszenia i opuszczania tadunku wielkogabarytowego [9]

Wyniki symulacji typu MBS stanowią dane wejściowe do analiz numerycznych, wykorzystujących metodę elementów skończonych (Finite Element Method). Oprócz przedstawionych powyżej wyników (parametry siłowe), można uzyskać dane dotyczące wartości przyspieszeń i opóźnień działających na środek techniczny, a tym samym na operatora, w tzw. stanach awaryjnych. Stany awaryjne związane są zwykle z nieprawidłowym użytkowaniem środka transportu lub jego uszkodzeniem, np. jazdą z niedozwoloną prędkością, aktywacją hamulców w nieprawidłowej konfiguracji zespołu transportowego czy uderzeniem o przeszkodę. Gwałtowane zatrzymanie lub zmiana kierunku jazdy może spowodować uraz operatora lub pasażerów. Identyfikacja tego typu zagrożeń wymaga specjalistycznego oprogramowania do symulowania zjawisk szybkozmiennych. Modele obliczeniowe powinny zawierać cechy antropometryczne, umożliwiające obliczanie parametrów biomechanicznych. Są to wirtualne odpowiedniki manekinów stosowanych w testach zderzeń komunikacyjnych. Na rysunku 17 przedstawiono skutek jazdy kolejką podwieszoną, z prędkością $5 \mathrm{~m} / \mathrm{s}$ na zakręcie o promieniu $4 \mathrm{~m}$.

Wspomaganie komputerowe obejmuje nie tylko fazę projektowania, ale służy również użytkownikom kolejek podwieszonych. Zgodnie z Rozporzadzeniem
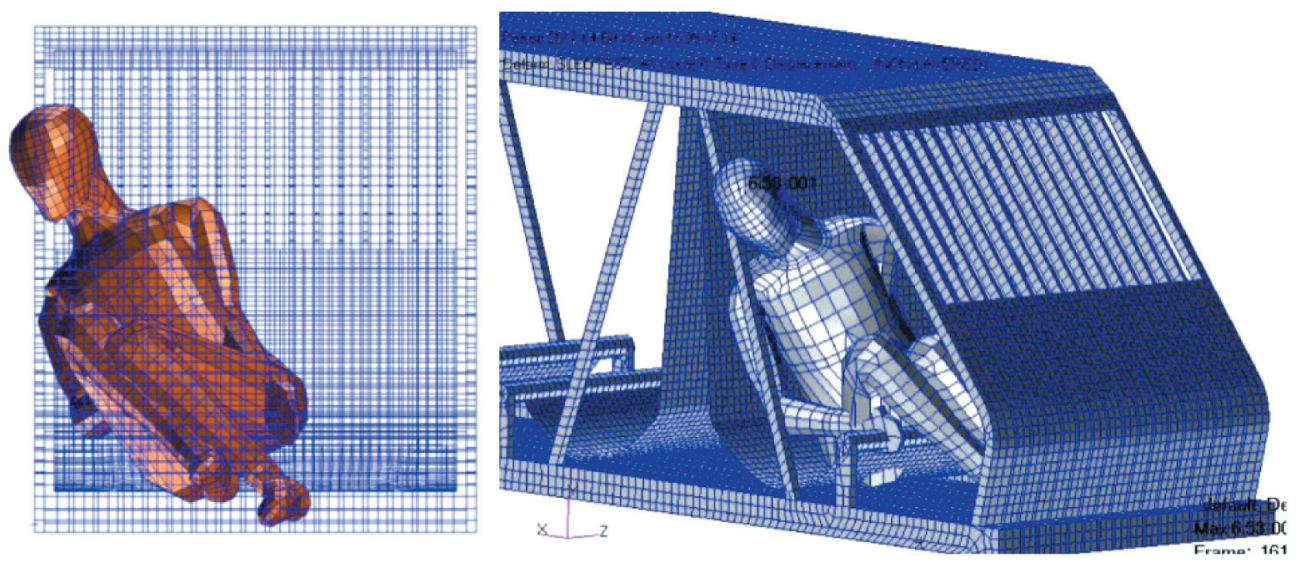

Rys. 17. Zachowanie się wirtualnego modelu manekina Hybrid III podczas jazdy kabina osobowa na zakręcie z prędkościa $5 \mathrm{~m} / \mathrm{s}$ [10] 
Ministra Energii z dnia 23 listopada 2016 r. w sprawie szczegótowych wymagań dotyczacych prowadzenia ruchu podziemnych zakładów górniczych, użytkownicy środków górniczego transportu podwieszonego zobowiązani są do dokonywania obliczeń trakcyjnych. W Instytucie KOMAG opracowano system STD (Safe Trans Design), który umożliwia odpowiedni dobór komponentów zespołu transportowego, np. ciągnika, wózków hamulcowych, zestawów nośnych, do konkretnych warunków prowadzenia transportu.

W przypadku transportu podwieszonego warunki te określone są przez nachylenie wyrobiska, w którym prowadzony jest transport, a także parametry trasy podwieszonej, takie jak długość, profil i typ szyn oraz nośność zawiesi. Wyniki obliczeń dostarczają informacji o maksymalnej masie netto transportowanego ładunku, drodze hamowania, opóźnieniu hamowania, rozkładzie sił wzdłużnych w cięgłach zespołu transportowego, a także umożliwiają analizę kolizyjności podczas transportu materiałów wielkogabarytowych.

System STD stanowi wsparcie służb kopalnianych w zakresie tworzenia dokumentacji układu transportu z zastosowaniem kolejek podwieszonych, dzięki minimalizacji błędów podczas konfigurowania kolejek podwieszonych i dokonywaniu obliczeń trakcyjnych, co przekłada się na poprawę bezpieczeństwa pracy.

\section{PERSPEKTYWY ROZWOJU TRANSPORTU PODWIESZONEGO}

Rozwój w dziedzinie kolejek podwieszonych w kopalniach węgla kamiennego należy rozważyć, uwzględniając następujące aspekty:

- warunki górniczo-geologiczne, w jakich są i będą wykonywane wyrobiska transportowe,

- parametry transportowanych ładunków (masy jednostkowe oraz wymiary),

- wymagany poziom bezpieczeństwa prowadzenia prac transportowych,

- aktualnie stosowane środki transportu, zwłaszcza w aspekcie ich efektywności,

- konkurencyjność przewidywanych nowych środków transportu,

- minimalizacja skutków oddziaływania na środowisko naturalne,

- uwarunkowania ekonomiczne - celowość i opłacalność zastosowania nowych środków transportu.
Mając na uwadze poczynione inwestycje, nie należy oczekiwać radykalnego zastąpienia napędów spalinowych napędami akumulatorowymi. W związku z tym należy w stosunkowo krótkim czasie oczekiwać:

- zmniejszenia emisji szkodliwych składników spalin,

- zmniejszenia emisji ciepła i hałasu ze spalinowej jednostki napędowej.

Przewiduje się, że warunki wentylacyjne wymuszą w perspektywie wprowadzenie napędów elektrycznych. Stąd należy spodziewać się rozwoju tych napędów, nie tylko akumulatorowych, ale także zasilanych zewnętrznie, np. z szynoprzewodu.

Dynamiczny rozwój napędów nie przełożył się na zwiększenie możliwości obciążania tras jezdnych, wynikających ze wskaźników wytrzymałościowych szyn, złącz szynowych oraz stosowanych sposobów podwieszenia trasy. Obciążenie nominalne zawiesi mocowanych do łuków obudowy podatnej ŁP z uwagi na wymagania obowiązujących przepisów ograniczone jest do $40 \mathrm{kN}$, co praktycznie wyklucza możliwość transportu maszyn i urząazzeń o większych - skupionych masach z wykorzystaniem szynowych kolejek podwieszonych. Zwiększenie obciążenia złączy szynowych w kierunku zawieszenia jest możliwe np. w wyniku zastosowania trawersy wyrównującej obciążenie w zawiesiach (rys. 18).

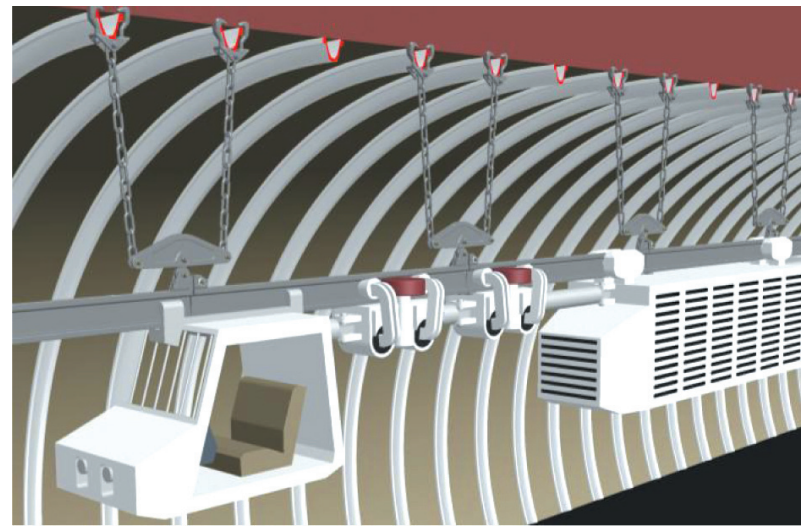

Rys. 18. Podwieszenie toru jezdnego do łuków obudowy z wykorzystaniem trawersy wyrównującej obciążenie zawiesi (maksymalne obciążenie złacza szynowego w kierunku zawieszenia $80 \mathrm{kN}$ ) [11]

Do dziś nie opracowano metod obliczeń dynamicznych, np. podczas hamowania kolejki, a zwłaszcza hamowania awaryjnego. Opracowanie metod określających sily dynamiczne w elementach trasy jest bardzo oczekiwane zarówno przez projektantów, jak 
i użytkowników, zwłaszcza w aspekcie analiz możliwości zwiększenia maksymalnej prędkości kolejek (obecnie $2 \mathrm{~m} / \mathrm{s}$ ). Specjaliści Instytutu KOMAG przeprowadzili zatem $\mathrm{w}$ podziemnym wyrobisku rejestrację sił $\mathrm{w}$ zawiesiach podczas hamowania, w tym hamowania awaryjnego - ze względów bezpieczeństwa, przy znacznie ograniczonych prędkościach.

Czwarta rewolucja przemysłowa (INDUSTRY 4.0) wprowadzi do powszechnej praktyki systemy automatyzacji, wizualizacji i monitoringu. Jeśli chodzi o kolejki podwieszone, należy przewidywać powszechne wdrożenie systemów kontroli ruchu umożliwiających bieżącą lokalizację kolejek w podziemiach kopalń. Przewiduje się również powszechne zastosowanie technologii RFID [12, 13]. Systemy te będą funkcjonować na podstawie bezprzewodowej transmisji danych informujących o lokalizacji środków transportowych, a także o ich stanie technicznym. Istotną częścią systemów stanie się oprogramowanie w celu ostrzegania i alarmowania w awaryjnych sytuacjach, co przyczyni się do poprawy bezpieczeństwa pracy na kopalnianych drogach transportowych.

\section{Literatura}

[1] Mitręga J. (red.): Rozwój mechanizacji robót podziemnych w kopalniach wegla kamiennego w PRL, Wydawnictwo Śląsk, Katowice 1967.

[2] Kovalik M.: Vykonnejsia viacdielna zavesna lokomotiva LZH-50. D.3, „Spravodaj” 1988, 1: 11-20.

[3] Marciniak Z., Jałmużna J.: Perspektywy rozwoju pomocniczego transportu podziemnego w świetle oferty FMG „PIOMA” S.A., „Miesięcznik WUG” 2002, 3: 30-34.
[4] Pieczora E.: Prace prowadzone przez CMG KOMAG w zakresie dołowych i powierzchniowych waskotorowych lokomotyw spalinowych, Sympozjum nt. „Dołowe i powierzchniowe wąskotorowe lokomotywy spalinowe w kopalniach PW", CMG KOMAG, Gliwice 1990.

[5] Pieczora E., Suffner H.: Rozwój napędów dołowych kolejek podwieszonych, „Maszyny Górnicze” 2017, 3: 44-57.

[6] Fuksa D., Kęsek M., Ślósarz M., Bator A.: Koncepcja zintegrowanego systemu transportu poziomego $w$ kopalniach węgla kamiennego, „Przegląd Górniczy” 2015, 8: 23-25.

[7] Pieczora E.: Prognoza rozwoju szynowych systemów transportowych stosowanych $w$ podziemiach kopaln wegla kamiennego, „Gospodarka Surowcami Mineralnymi” 2008, 24, 1/2: 221-232.

[8] Pieczora E., Polnik B.: Nowe rozwiązania napędów elektrycznych do górniczych maszyn transportowych, „Cuprum” 2015, 3: $199-210$.

[9] Szewerda K., Tokarczyk J., Turewicz A.: Metoda wyznaczania sit dynamicznych $w$ wysokoobciażalnych modułowych zestawach transportowych za pomoca analiz MBS, ITG KOMAG 2014, [praca niepublikowana].

[10] Tokarczyk J.: Wirtualne prototypowanie systemów mechanicznych $w$ górnictwie, ITG KOMAG 2014, [praca niepublikowana].

[11] Mrowiec H., Raszka W., Dyrda J.: Zawiesia torów jezdnych szynowych kolejek podwieszonych, Konferencja „Bezpieczeństwo pracy urządzeń transportowych w górnictwie", Centrum Badań i Dozoru Górnictwa Podziemnego, Ustroń 2010.

[12] Michalak D.: Applying the Augmented Reality and RFID Technologies in the Maintenance of Mining Machines, Proceedings of the World Congress on Engineering and Computer Science, San Francisco, USA 2012.

[13] Rogala-Rojek J., Jasiulek D., Latos M., Piecha A., Woszczyński M., Stankiewicz K.: iRIS - System identyfikacji maszyn, urządzeń, środków trwatych oraz transportu, ITG KOMAG 2012, [praca niepublikowana].

dr inż. EDWARD PIECZORA dr inż. JAROSEAW TOKARCZYK Instytut Techniki Górniczej KOMAG ul. Pszczyńska 37, 44-101 Gliwice \{epieczora,jtokarczyk\}@komag.eu 